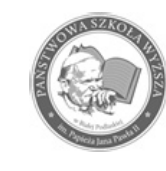

ol. 11, No. 1, 2018

www.ers.edu.pl

PF OPEN ACCESS eISSN 2451-182X

Authors' contribution/

Wkład autorów:

A. Zaplanowanie badań/

Study design

B. Zebranie danych/

Data collection

C. Analiza statystyczna/

Statistical analysis

D. Interpretacja danych/

Data interpretation

E. Przygotowanie tekstu/

Manuscript preparation

F. Opracowanie

piśmiennictwa/

Literature search

G. Pozyskanie funduszy/

Funds collection
ECONOMIC AND REGIONAL STUDIES

STUDIA EKONOMICZNE I REGIONALNE

ISSN 2083-3725

Volume 11, No. 1, 2018

\section{REGIONAL VARIATION IN CHANGES IN AGRICULTURAL PRODUCTION IN POLAND IN THE CONTEXT OF ENVIRONMENTAL IMPACT*}

\section{REGIONALNE ZRÓŻNICOWANIE ZMIAN PRODUKCJI ROLNICZEJ W POLSCE W KONTEKŚCIE ODDZIAEYWANIA NA ŚRODOWISKO*}

\author{
Jerzy Kopiński ${ }^{1(\mathrm{~A}, \mathrm{~B}, \mathrm{C}, \mathrm{D}, \mathrm{E}, \mathrm{F}, \mathrm{G})}$
}

${ }^{1}$ Institute of Soil Science and Plant Cultivation - State Research Institute in Puławy Instytut Uprawy Nawożenia i Gleboznawstwa - Państwowy Instytut Badawczy w Puławach

Kopiński J. (2018), Regional variation in changes in agricultural production in Poland in the context of environmental impact/ Regionalne zróżnicowanie zmian produkcji rolniczej $w$ Polsce $w$ kontekście oddziaływania na środowisko. Economic and Regional Studies, Vol. 11, No. 1, pp. 59-75.

https://doi.org/10.29316/ers-seir.2018.05

\section{ORIGINAL ARTICLE}

JEL code: Q15, Q51, Q56

Submitted:

August 2017

Accepted:

December 2017

Tables: 0

Figures: 12

References: 47

\section{ORYGINALNY ARTYKUŁ} NAUKOWY

Klasyfikacja JEL: Q15, Q51, Q56

Zgłoszony:

Sierpień 2017

Zaakceptowany:

Grudzień 2017

Tabele: 0

Rysunki: 12

Literatura: 47

\section{Summary}

Subject and purpose of work: Agricultural production activity brings about specific environmental effects. The aim of the study was to analyse changes in agricultural production in regions of Poland (NUTS-2) in the context of environmental impact using the gross nitrogen balance.

Materials and methods: The analysis covered the medium-term perspective of 2001-2016. The primary source of information was statistical data of the Polish Central Statistical Office (Główny Urząd Statystyczny - GUS).

Results: During the 2002-2004 period, the balance of gross nitrogen balance in Poland did not change and amounted to an average of $47.5 \mathrm{~kg} \mathrm{~N} \cdot \mathrm{ha}-1$ UAA (Utilized Agricultural Area). The progressive extensification of plant production in the following provinces: Slaskie, Malopolskie, Podkarpackie and Swietokrzyskie, is accompanied by a rapid reduction in the stocking density of livestock.

Conclusions: The nitrogen balance, highly differentiated regionally, just as its individual elements, show the potential differentiation scale of the agricultural impact on the state of the environment. Very high balance surpluses occurring in the Kujawsko-Pomorskie, Lodzkie and Wielkopolskie provinces may indicate high environmental pressure from the agricultural production.

Keywords: regional differentiation of agriculture, agricultural production, production intensity, environmental impact of agriculture, gross nitrogen balance

\section{Streszczenie}

Przedmiot i cele pracy: Działalności produkcji rolniczej niesie ze sobą określone skutki środowiskowe. Celem opracowania była analiza zmian produkcji rolniczej w regionach Polski (NUTS-2) w kontekście oddziaływania na środowisko z wykorzystaniem bilansu azotu brutto.

Materiały i metody: Analiza obejmowała perspektywę średniookresową lat 2001-2016. Podstawowe źródło informacji stanowiły dane statystyczne Głównego Urzędu Statystycznego (GUS).

Wyniki: W latach 2002-2004 saldo bilansu azotu brutto w Polsce nie uległo zmianie i wynosiło średnio 47,5 kg N·ha-1 UR. Postępującej ekstensyfikacji produkcji roślinnej w województwach: śląskim, małopolskim, podkarpackim, świętokrzyskim towarzyszy gwałtowne zmniejszenie obsady zwierząt gospodarskich. Wnioski: Silnie zróżnicowane regionalnie sald bilansu azotu jak i jego poszczególnych elementów pokazują potencjalną skalę zróżnicowania oddziaływania rolnictwa na stan środowiska. Bardzo duże nadwyżki bilansowe występujące w województwach kujawsko-pomorskim, łódzkim i wielkopolskim, wskazywać mogą na dużą presję środowiskową ze strony produkcji rolniczej.

Słowa kluczowe: regionalne zróżnicowanie rolnictwa, produkcja rolnicza, intensywność produkcji, oddziaływanie środowiskowe rolnictwa, bilans azotu brutto

${ }^{*}$ The article was prepared as part of task No. 2.1 in the 2014-2020 long-term program of the Institute of Soil Science and Plant Cultivation State Research Institute/ ${ }^{*}$ Artykuł opracowano w ramach zadania nr $2.1 \mathrm{w}$ programie wieloletnim 2014-2020 IUNG-PIB

Address for correspondence/ Adres korespondencyjny: dr hab. Jerzy Kopiński (ORCID 0000-0002-2887-4143), Instytut Uprawy Nawożenia i Gleboznawstwa - Państwowy Instytut Badawczy, Zakład Systemów i Ekonomiki Produkcji Roślinnej, ul. Czartoryskich 8, 24-100 Puławy, Polska; tel. +48 81 47868 21, e-mail: jkop@iung.pulawy.pl

Journal indexed in/ Czasopismo indeksowane w: AgEcon Search, AGRO, BazEkon, Index Copernicus Journal Master List, ICV 2016: 92,91; Polish Ministry of Science and Higher Education 2016: 9 points/ AgEcon Search, AGRO, BazEkon, Index Copernicus Journal Master List ICV 2016: 92.91; Ministerstwie Nauki i Szkolnictwa Wyższego 2016: 9 punktów. Copyright: (C) 2018 Pope John Paul II State School of Higher Education in Biała Podlaska, Jerzy Kopiński. All articles are distributed under the terms of the Creative Commons Attribution-NonCommercial-ShareAlike 4.0 International (CC BY-NC-SA 4.0) License (http://creativecommons.org/licenses/by-nc-sa/4.0/), allowing third parties to copy and redistribute the material in any medium or format and to remix, transform, and build upon the material, provided the original work is properly cited and states its license. 


\section{Introduction}

Agriculture, like many other branches of the economy, undergoes constant economic and structural changes, which necessitate processes of adjustment to variable economic conditions (Kopiński 2017d). The changes taking place are a derivative of the function of elapsing time (Matyka et al. 2013) and a derivative of civilizational and cultural changes distinctive in the general level and quality of rural population's life in the local and national scale (Niedzielski 2015), but also of urban residents (as food consumers). Runowski (2014) points out that the impact of various dimensions of the environment, i.e. economic, technological, international, ecological, political and legal as well as sociocultural ones, on the whole agro-food sector is increasingly high and it occurs in close, mutually interweaving relations.

Apart from internal conditions (including: natural, organizational and economic ones), the external factors are also influential, among other things, the ones that are shaped by the CAP (Common Agricultural Policy), WTO (World Trade Organization ${ }^{1}$, raw materials, product and capital markets, or current and future international agreements - CETA (Comprehensive Economic and Trade Agreement ${ }^{2}$ ), TTIP (Transatlantic Trade and Investment Partnership ${ }^{3}$ ).

Every sudden (and not only such) change, within the scope of conducted agricultural activity, forces one to make decisions and take actions restoring the desired state of specific economic balance (Józwiak 2013). These changes affect also the intensity level, the structure of agricultural production, but also the state of the environment. The scale (power of pressure) of the impact of agricultural production depends directly on the level of production intensity and compliance with the so-called good agricultural culture rules, which are specified in many rules of law, statements and regulations (Strategy... 20124; Principle... 20125). The concept of multifunctional agriculture included therein as part of the Common Agricultural Policy (CAP) is intended to support the so-called European agricultural model (RDP Rural Development Programme 2009, 2014), that is "moderately" intensive agricultural production carried out in accordance with the principles of protection, preservation and improvement of the natural environment. At the same time in Poland, the processes of increasing intensity, concentration, specialization and polarization of agricultural production are noticeable. They arise from the aspiration to improve the rate of return and profitability of farmland management (Kopiński, Krasowicz 2010; Józwiak, Mirkowska 2011; Ziętara 2009) in the conditions of increasing competition

\footnotetext{
${ }^{1}$ WTO - World Trade Organisation

${ }^{2}$ CETA - Comprehensive Economic and Trade Agreement (EUCanada)

${ }^{3}$ TTIP - TransatlanticPartnership in the field of Trade and Investment (EU-US)

${ }^{4}$ Strategy for sustainable development of rural areas, agriculture and fishing for 2012-2020, MARD, Warsaw 2012, pp. 155

${ }^{5}$ Cross-compliance, MARD, Warsaw 2012, pp. 64.
}

\section{Wstęp}

Rolnictwo, tak jak wiele innych gałęzi gospodarki, ulega ciągłym przemianom ekonomicznym i strukturalnym, które wymuszają procesy dostosowawcze do zmieniających się warunków gospodarowania (Kopiński 2017d). Zachodzące zmiany są pochodną funkcji upływającego czasu (Matyka i in. 2013) i pochodną zmian cywilizacyjno-kulturowych wyrażających się w ogólnym poziomie i jakości życia mieszkańców wsi w skali lokalnej i ogólnokrajowej (Niedzielski 2015), ale także mieszkańców miast (jako konsumentów żywności). Runowski (2014) zwraca uwagę że, oddziaływanie różnych wymiarów otoczenia, tj. ekonomicznego, technologicznego, międzynarodowego, ekologicznego, polityczno-prawnego i społeczno-kulturowego na cały sektor rolno-żywnościowy jest coraz większe i zachodzi w ścisłych, wzajemnie przenikających się powiązaniach.

Poza uwarunkowaniami wewnętrznymi (w tym: przyrodniczymi, organizacyjno-ekonomicznymi) znaczący wpływ mają także czynniki zewnętrzne kształtowane m.in. przez WPR (Wspólna Polityka Rolna), WTO (World Trade Organization ${ }^{1}$ ), rynki surowcowe, produktowe i kapitałowe, czy obecne i przyszłe umowy międzynarodowe - CETA (Comprehensive Economic and Trade Agreement ${ }^{2}$ ), TTIP (Transatlantic Trade and Investment Partnership ${ }^{3}$ ).

Każda gwałtowna (i nie tylko) zmiana, w obrębie prowadzonej działalności rolniczej, wymusza podejmowanie decyzji i działań przywracających pożądany stan swoistej równowagi ekonomicznej (Józwiak 2013). Zmiany te oddziałują także na poziom intensywności, strukturę produkcji rolniczej, ale także na stan środowiska. Skala (siła presji) odziaływania produkcji rolniczej zależy bezpośrednio od poziomu intensywności produkcji i przestrzegania zasad tzw. dobrej kultury rolnej, ujętych w wielu normach prawnych, deklaracjach i rozporządzeniach (Strategia... 2012 $2^{4}$; Zasada... 20125). Ujęta w nich koncepcja rolnictwa wielofunkcyjnego $\mathrm{w}$ ramach prowadzonej Wspólnej Polityki Rolnej (WPR) wspierać ma tzw. europejski model rolnictwa (PROW 2009; 2014), czyli „umiarkowanie" intensywną produkcję rolną prowadzoną w zgodzie z zasadami ochrony, zachowania i poprawiania środowiska naturalnego. Jednocześnie w Polsce widoczne są procesy wzrostu intensywności, koncentracji, specjalizacji i polaryzacji produkcji rolniczej. Wynikają one $\mathrm{z}$ dążenia do poprawy rentowności i dochodowości gospodarowania (Kopiński, Krasowicz 2010; Józwiak, Mirkowska 2011; Ziętara 2009) w warunkach coraz bardziej wzrastającej konkurencji (krajowej, europejskiej i światowej). Podejmowane działania (regulacje prawne) przeciwdziałające negatywnym skutkom działalności rolniczej

\footnotetext{
${ }^{1}$ WTO - Światowa Organizacja Handlu

${ }^{2}$ CETA - Kompleksowa Umowa Gospodarczo-Handlowa (UE-Kanada)

${ }^{3}$ TTIP - Transatlantyckie Partnerstwo w dziedzinie Handlu i Inwestycji (UE-USA)

${ }^{4}$ Strategia zrównoważonego rozwoju wsi, rolnictwa i rybactwa na lata 2012-2020, MRiRW, Warszawa 2012, ss. 155.

${ }^{5}$ Zasada Wzajemnej Zgodności (cross-compliance), MRiRW, Warszawa 2012, ss. 64.
} 
(domestic, European and worldwide). The actions undertaken (legal regulations) to counteract the negative effects of agricultural activity will not fully eliminate the existing threats, but rather they are intended to play a restrictive role.

The environmental effects of agricultural production may be manifested directly in a measurable way through the change of soil fertility indicators and in the composition and quality of groundwater or indirectly in the change of the socalled agro-environmental indicators informing about the potential (possible) impact of agriculture (Fotyma et al. 2010; Kopiński 2010). One of many such indicators, in addition to the consumption of chemical plant protection products and energy, used and required, among others, by Eurostat and OECD $^{6}$ (Organization for Economic Cooperation and Development) is the balance of nutrients, including nitrogen and phosphorus, being the main biogens (Kopiński 2017a; Pastuszak et al. 2014).

However, it should be emphasised that the provinces (regions) of Poland, by virtue of the diversity of natural, organizational and economic conditions, and also environmental ones, are not areas of homogeneous agriculture and the importance of regionalization of agricultural development is still on the rise (Kopiński 2017d, Kopiński, Matyka 2016; Rudnicki et al. 2015; Stany 2013). Therefore, on account of its complexity, the evaluation of the effects of occurring changes and processes in agricultural production in relation to production-economic and environmental objectives, is highly diverse and ambiguous, and generally conflicting (Kopiński 2012; Zegar 2013).

The aim of the study is to analyse changes in agricultural production in Poland's regions (NUTS$2^{7}$ ) in the context of environmental impact using the gross nitrogen balance.

\section{Materials and the method}

The research and analysis were conducted in a desk research manner. They covered the mediumterm perspective of the period 2001-2016. The primary source of information was statistical data of the Polish Central Statistical Office (CSO) and results of proprietary research. The research used the analysis of the structure of the phenomena (features) and the dynamics of changes in relative terms or when described by a trend equation. In spatial comparative analysis, the indicators for individual provinces were confronted with the mean figures for Poland, as a reference system. In order to eliminate the influence of variability over the years, the analysis of basic indicators was based on mean values from 3 years. To indicate emerging trends, changes in individual regions between the periods 2001-2003 and 20132015 or 2014-2016 were compared (depending on the availability of data).

\footnotetext{
${ }^{6}$ Environmental Indicators for Agriculture. Publications Service OECD, Paris, 2006, vol. 4, chapter 3.

${ }^{7}$ NUTS - Nomenclature of TerritorialUnits for Statistics (Nomenclature of TerritorialUnits for Statistics)
}

nie wyeliminują występujących zagrożeń do końca, a raczej mają pełnić rolę ograniczającą.

Skutki środowiskowe działalności produkcji rolniczej mogą ujawniać się bezpośrednio w mierzalny sposób w zmianie wskaźników żyzności gleby oraz w składzie i jakości wód gruntowych lub pośrednio w zmianie tzw. wskaźników agro-środowiskowych informujących o potencjalnym (ewentualnym) oddziaływaniu rolnictwa (Fotyma i in. 2010; Kopiński 2010). Jednymi z wielu takich wskaźników, obok zużycia chemicznych środków ochrony roślin oraz energii, stosowanych i wymaganych m.in. przez Eurostat i $\operatorname{OECD}^{6}$ (Organisation for Economic Cooperation and Development) są bilanse składników nawozowych, w tym azotu i fosforu, jako głównych biogenów (Kopiński 2017a; Pastuszak i in. 2014).

Należy jednak podkreślić, że województwa (regiony) Polski, ze względu na różnorodność warunków przyrodniczych i organizacyjno-ekonomicznych, ale także środowiskowych, nie są obszarami o jednolitym rolnictwie i znaczenie regionalizacji rozwoju rolnictwa ciągle wzrasta (Kopiński 2017d, Kopiński, Matyka 2016; Rudnicki i in. 2015; Stany 2013). Dlatego ocena skutków zachodzących zmian i procesów w produkcji rolniczej w odniesieniu do celów produkcyjno-ekonomicznych i środowiskowych, ze względu na złożoność, jest mocno zróżnicowana i niejednoznaczna, a na ogół przeciwstawna (Kopiński 2012; Zegar 2013).

Celem opracowania jest analiza zmian produkcji rolniczej w regionach Polski (NUTS-2 ${ }^{7}$ ) w kontekście oddziaływania na środowisko z wykorzystaniem bilansu azotu brutto.

\section{Materiał i metoda}

Badania i analiza miały charakter kameralny. Obejmowały one perspektywę średniookresową lat 2001-2016. Podstawowe źródło informacji stanowiły dane statystyczne Głównego Urzędu Statystycznego (GUS) i wyniki badań własnych. W badaniach wykorzystano analizę struktury zjawisk (cech) oraz dynamikę zmian $\mathrm{w}$ ujęciu względnym lub opisanej równaniem trendu. W przestrzennej analizie porównawczej wskaźniki dla poszczególnych województw skonfrontowano ze średnimi dla Polski, jako układem odniesienia. W celu wyeliminowania wpływu zmienności w latach, analizę podstawowych wskaźników oparto na średnich z 3 lat. Dla wskazania zachodzących tendencji porównywano zmiany zachodzące w poszczególnych regionach pomiędzy okresem lat 2001-2003 a 2013-2015 lub 2014-2016 (w zależności od dostępności danych).

\footnotetext{
${ }^{6}$ Environmental Indicators for Agriculture. Publications Service, OECD, Paris, 2006, vol. 4, chapter 3.

${ }^{7}$ NUTS - Nomenklatura Jednostek Terytorialnych do Celów Statystycznych (Nomenclature of Territorial Units for Statistics)
} 
The values of the analysed indicators were referred to the area of utilized agricultural area maintained in a good culture $\left(U^{2} A^{8}\right)$. Indicators describing production and organizational conditions, as well as environmental ones, were used in the research. Crop harvest was converted into cereal units $(100$ $\mathrm{kg}$ of cereal grain) according to the rules existing in agricultural economics (Harasim 2006). Conversions of animals into livestock units (LU) were made on the basis of the coefficients given in the Regulation of the Ministry of Agriculture and Rural Development.9

The paper attempts to describe the phenomena (processes) of concentration, polarization and intensification of agricultural production through the analysis of cause and effect relationships.

\section{Research results and discussion}

The resources of agricultural land (AL) in Poland, in relation to Europe, viewed as a key factor of agricultural production, are considerable. Currently, the area of farmland in a good culture amounts to approx.14.2 million ha (about $45 \%$ of the country area), and the rest of the farmland, in the approach of geodesy, consists of land allocated for non-agricultural purposes, mainly grounds for rural infrastructure. The analysis carried out for the purposes of this study shows that in Poland, since the beginning of the 21st century, there has been a continuous decline in the area of agricultural land. Over the last 16 years, the AL area in Poland has decreased on a national scale by nearly 4 million hectares from 18.4 million hectares in 2000 to 14.5 million hectares in 2016 (Fig. 1). According to the equation describing this trend, on average, the AL area decreased by 219 thousand hectares yearly. The changes in the AL area resulted mainly from the decrease in the arable land (ArL) area, whose rate of decline is close to the pace of the AL decrease in Poland. As a consequence, the possibilities of using the agricultural land resources to conduct agricultural production in Poland in consecutive years have become more and more limited, thus determining the processes of its concentration and intensity growth per unit area (1 ha).

The rate of agricultural land loss land is not equal in all provinces. During the period of 2002-2016, the AL area suffered the biggest decrease (by over $20 \%$ ), in the provinces hitherto characterised by the extensive nature of agricultural production, i.e. SlaskieSilesian, Dolnoslaskie, Podkarpackie and Swietokrzyskie. (Fig. 2). The process of shutting down and phasing out agricultural production is the strongest there. All these provinces belong to the so-called "Małopolska and Pogórze" macro-region, distinguished according to the division used by FADN $^{10}$ (Goraj 2000). Such a significant loss of agriculturally used area, in the

\footnotetext{
${ }^{8}$ UAA - utilized agricultural area in good culture (agriculturally used); according to the CSO definition.

${ }^{9} \mathrm{LU}$ - a livestock unit according to the Ministry of Agriculture and Rural Development based on the annex to the ordinance of the Council of Ministers of November 9, 2004 (Dz. U. No. 257, item. 2573, 2004).

${ }^{10}$ FADN - Farm Accountancy Data Network (pol. Accountancy Data
} Network Farm)
Wielkości analizowanych wskaźników odnoszono do powierzchni użytków rolnych utrzymywanych w dobrej kulturze (UR w dk. ${ }^{8}$ ). W badaniach zastosowano wskaźniki opisujące warunki produkcyjno-organizacyjne oraz środowiskowe. Plony roślin uprawnych przeliczono na jednostki zbożowe (100 kg ziarna zbóż) według zasad obowiązujących w ekonomice rolnictwa (Harasim 2006). Przeliczenia zwierząt na duże jednostki przeliczeniowe (DJP) dokonano na podstawie współczynników podanych w rozporządzeniu MRiRW ${ }^{9}$.

W pracy podjęto próbę opisu zjawisk (procesów) koncentracji, polaryzacji i intensyfikacji produkcji rolniczej poprzez analizę zależności przyczynowo -skutkowych.

\section{Wyniki badań i dyskusja}

Zasoby ziemi uprawnej w Polsce $\mathrm{w}$ odniesieniu do Europy, jako podstawowego czynnika produkcji rolniczej, są znaczne. Powierzchnia użytków rolnych w dobrej kulturze wynosi obecnie ok.14,2 mln ha (ok. $45 \%$ powierzchni kraju), a resztę użytków rolnych w ujęciu geodezyjnym stanowią grunty wyłączone na cele nierolnicze, głównie tereny pod infrastrukturą wiejską. Z przeprowadzonej na potrzeby tego opracowania analizy wynika, że w Polsce od początku XXI w. następuje ciągły ubytek powierzchni użytkowanej rolniczo. W okresie ostatnich 16 lat powierzchnia UR w skali kraju zmniejszyła się blisko o $4 \mathrm{mln}$ ha z 18,4 mln ha w 2000 r. do $14,5 \mathrm{mln}$ ha w 2016 r. (rys. 1). Według równania opisującego ten trend, przeciętnie w ciągu roku powierzchnia uży tków rolnych zmniejszała się w tempie 219 tys. ha. Zasadniczo zmiany powierzchni UR wynikały głównie ze spadku powierzchni gruntów ornych (GO), których tempo spadku jest zbliżone do tempa zmniejszania się UR w Polsce. W konsekwencji, możliwości wykorzystania zasobu ziemi uprawnej do prowadzenia produkcja rolnicza w Polsce w kolejnych latach stają się coraz bardziej ograniczone, determinując w ten sposób procesy wzrostu jej koncentracji i intensywności na jednostce powierzchni (1 ha).

Tempo ubytku ziemi użytkowanej rolniczo nie jednakowe we wszystkich województwach. W okresie lat 2002-2016 powierzchnia użytków rolnych, najbardziej bo o ponad 20\%, zmniejszyła się w województwach charakteryzujących się dotychczas ekstensywnym charakterem produkcji rolniczej, tj. śląskim, małopolskim, podkarpackim, świętokrzyskim (rys. 2). Najsilniej zachodzi tu proces wyłączania i wygaszania produkcji rolniczej. Wszystkie te województwa należą do tzw. makroregionu „Małopolska i Pogórze" wyodrębnionych wg podziału stosowanego przez FADN ${ }^{10}$ (Goraj 2000). Tak znaczny ubytek powierzchni użytkowanej rolniczo, w kontekście dużego rozdrobnienia agrarnego, jest bardzo poważnym

\footnotetext{
${ }^{8} \mathrm{UR}$ w dk - uży tki rolne w dobrej kulturze (użytkowane rolniczo); wg definicji GUS

${ }^{9}$ DJP - duża jednostka przeliczeniowa wg MRiRW na podstawie załacznika do rozporządzenia Rady Ministrów z 9 listopada 2004 r. (Dz. U. Nr 257, poz. 2573, 2004).

${ }^{10}$ FADN - Farm Accountancy Data Network (pol. Sieć Danych Rachunkowości Gospodarstw Rolnych)
} 
context of high agrarian fragmentation, is a very serious limitation of the agricultural production potential in this region, also affecting the level of agricultural production and food security in the country. ograniczeniem potencjału produkcyjnego rolnictwa tego regionu, wywierając także wpływ na poziom produkcji rolniczej i bezpieczeństwo żywnościowe w kraju.

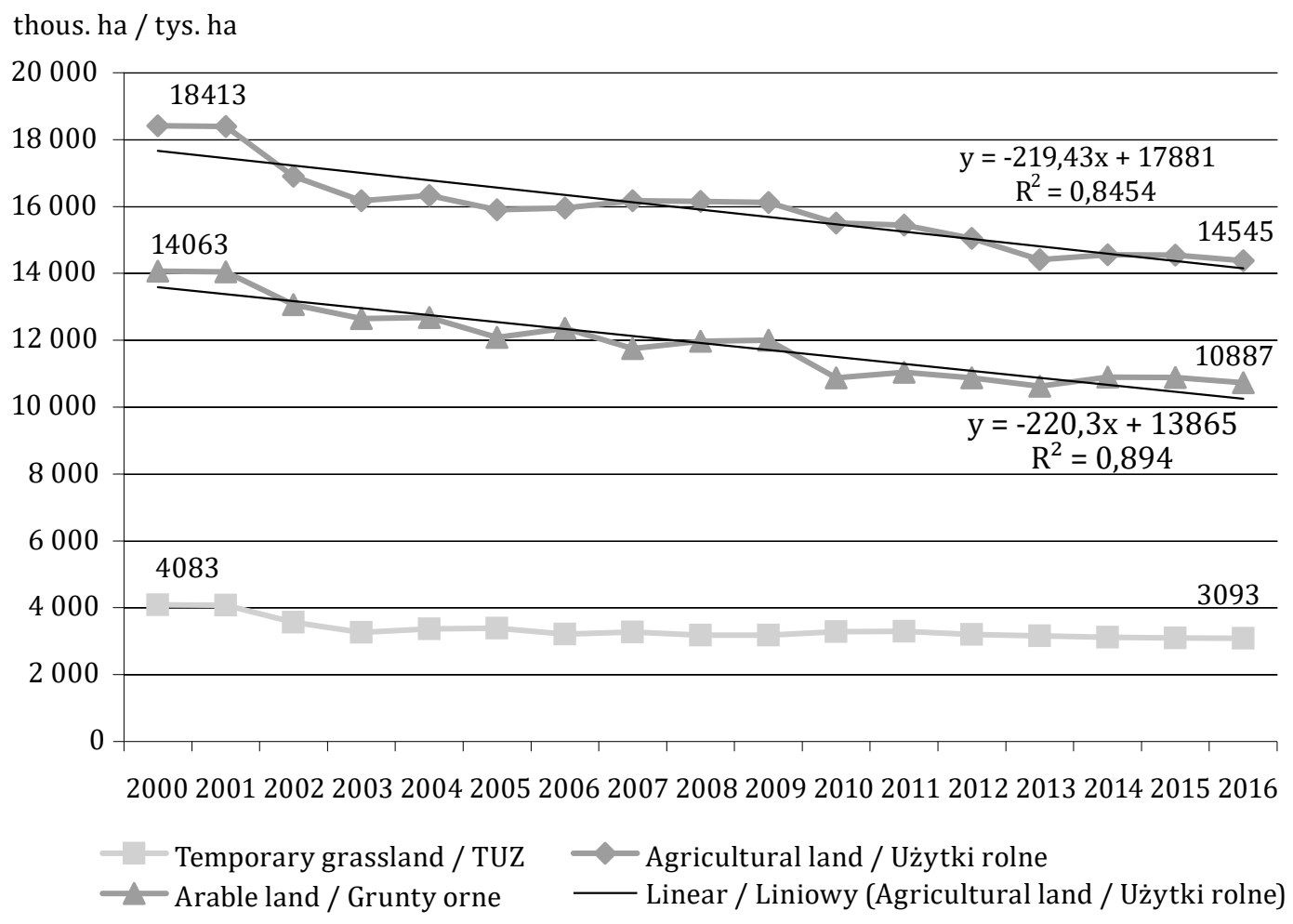

Figure 1. Changes in the area of agricultural land in Poland over the years 2000-2016

Rysunek 1. Zmiany powierzchni użytków rolnych w Polsce w latach 2000-2016

Source: Author's own elaboration based on CSO data: Land use... (2000-2017).

Źródło: opracowanie własne na podstawie danych GUS: Użytkowanie gruntów... (2000-2017).

In turn in the provinces with a high concentration of plant and animal production, where the average farm area exceeds 15 hectares, the agricultural land area does not decrease at such a drastic pace (Kujawsko-pomorskie, Opolskie, Podlaskie and Dolnoslaskie). The prices of agricultural land in these provinces belong to the highest in Poland ${ }^{11}$.

In Poland, the downward trend in the side of agricultural land area is accompanied by the trend of reducing the number of farms at the rate of $2.1 \%$ per year (Land use... 2000-2017), which, however, is not the same both in the regions and in farm area groups. The concentration of land in farms with an area exceeding 30 ha of AL, currently possessing more than $40 \%$ of agricultural land has been proceeding since the beginning of the 21st century (Fig. 3). The average AL area on a farm increased between 2000 and 2016 in all provinces (Land use... 2000-2017). Its greatest extent (pace), however, occurred in the provinces with the landconsuming type of production intensification, i.e.: Zachodniopomorskie, Opolskie, Lubuskie and Dolnoslaskie (over 65\%), and the least in relative

\footnotetext{
${ }^{11}$ Source: Agricultural Land Market. Market analysis. Pub. IAFE
} -NPI, APA, MARD. Warsaw, 2016, no. 19.
Natomiast w województwach o dużej koncentracji towarowej produkcji roślinnej i zwierzęcej, w których przeciętna powierzchnia gospodarstwa rolnego przekracza 15 ha, powierzchnia użytków rolnych nie zmniejsza się w tak znacznym stopniu (kujawsko-pomorskie, opolskie, podlaskie i wielkopolskie). Ceny gruntów rolnych w tych województwach należą do najwyższych w Polsce ${ }^{11}$.

W Polsce spadkowemu trendowi powierzchni ziemi rolniczej towarzyszy trend zmniejszenia liczby gospodarstw rolnych $\mathrm{w}$ tempie $2,1 \%$ rocznie (Użytkowanie gruntów... 2000-2017), którego nie jest jednak jednakowy zarówno w regionach i w grupach obszarowych gospodarstw. Od początku XXI wieku zachodzi koncentracja ziemi w gospodarstwach, których obszar przekracza 30 ha UR, posiadajacych obecnie już ponad $40 \%$ użytków rolnych (rys. 3). Średnia powierzchnia UR w gospodarstwie zwiększała się pomiędzy rokiem 2000 a 2016 we wszystkich województwach (Użytkowanie gruntów... 2000-2017), jednak w największym stopniu (tempie) następowało to województwach o ziemiochłonnym typie intensyfikacji produkcji, tj.: zachodniopomorskim, opolskim,

\footnotetext{
${ }^{11}$ Źródło: Rynek Ziemi Rolniczej. Analizy rynkowe. Wyd. IERiGŻ
} -PIB, ANR, MRiRW. Warszawa, 2016, nr 19. 
terms in Podlaskie, Malopolska, Lodzkie and Mazowieckie provinces. lubuskim i dolnośląskim (ponad 65\%), a najmniej w ujęciu względnym wzrosła ona w województwie podlaskim, małopolskim, łódzkim i mazowieckim.

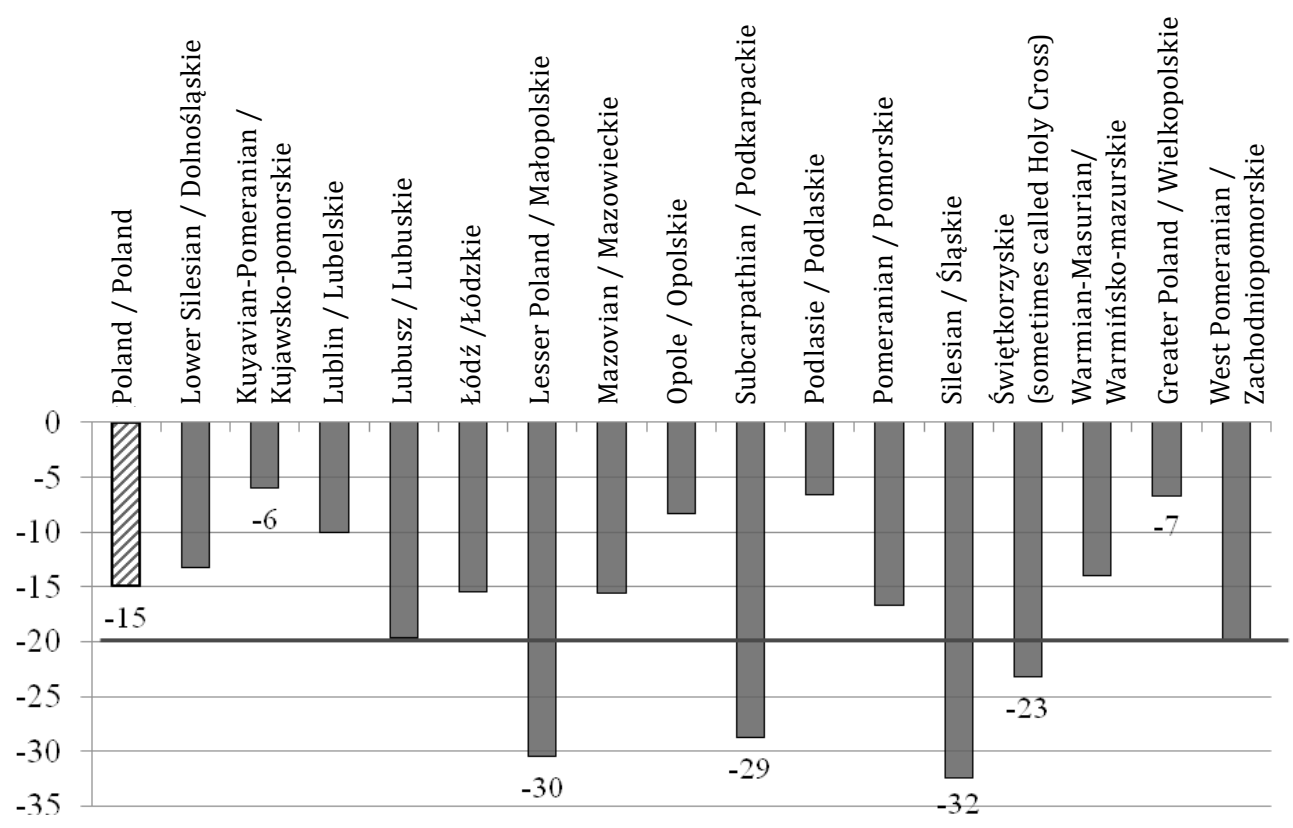

Figure 2. Changes in the area of agricultural land (\%) in provinces over the years 2002-2016 Rysunek 2. Zmiany powierzchni użytków rolnych (\%) w województwach w latach 2002-2016

Source: Author's own elaboration based on CSO data: Land use... (2002-2017).

Źródło: opracowanie własne na podstawie danych GUS: Użytkowanie gruntów... (2002-2017).

Diversified organisational and economic conditions had an impact on the changes in the structure of crops. In Poland in recent years (20142016) cereals have the largest share in the crop structure (approx. 71\%). This share, when compared to the years 2001-2003, decreased by 3.5 percentage points. The dynamics of changes in the share of cereals in the sown area in individual provinces is, however, varied (Fig. 4). The share of cereals in the structure of crops in the recent years increased the most in the Dolnoslaskie and Podkarpackie provinces (increase by approx. 10 percentage points), in which very small area farms dominate. Farmers (farm owners) abandon or do not undertake the cultivation of plants requiring considerable financial and technological contributions, and arable lands are sown with cereals and by maintaining them in a good culture the owners enjoy the possibility of obtaining direct subsidies. This constitutes a paradox of sorts, due to the landconsuming character of cereal cultivation. In the current conditions, however, it stems from the lack of alternative directions for agricultural production in the south-eastern regions of Poland.

The observed process of extensification of agricultural production in the south-eastern provinces of Poland, apart from the decrease in productivity, is also unfavourable in terms of the environment, leading to the reduction of biodiversity, soil fertility and their biological activity (Kuś 2012, Smagacz 2012). In the analysed period, the share of cereals in the area of crops in the Lubuskie, Podlaskie,
Zróżnicowane uwarunkowania organizacyjno -ekonomiczne miały wpływ na zachodzące zmiany w strukturze zasiewów. W Polsce w ostatnich latach (2014-2016) w strukturze zasiewów największy udział mają zboża (ok. 71\%). Udział ten w odniesieniu do lat 2001-2003 zmniejszył się o 3,5 p.p. Dynamika zmian udziału zbóż w powierzchni zasiewów w poszczególnych województwach jest jednak zróżnicowana (rys. 4). Udział zbóż w strukturze zasiewów w ostatnich latach najbardziej wzrastał w województwie małopolskim i podkarpackim (wzrost o ok. 10 p.p.), w których dominują bardzo małe obszarowo gospodarstwa. Rolnicy (właściciele) gospodarstw rezygnują, bądź nie podejmują uprawy roślin wymagających znacznych nakładów finansowych i technologicznych, a grunty orne obsiewają zbożami i utrzymując je w dobrej kulturze mają możliwość uzyskania dopłat bezpośrednich. Stanowi to swego rodzaju paradoks, ze względu na ziemiochłonny typ uprawy zbóż. Wynika to jednak w obecnych uwarunkowaniach z braku alternatywnych kierunków prowadzenia produkcji rolniczej w regionach Polski południowo-wschodniej.

Zaobserwowany proces ekstensyfikacji produkcji rolniczej w południowo-wschodnich województwach Polski, poza obniżeniem produkcyjności, jest także niekorzystny pod względem środowiskowym, prowadząc do ograniczenia bioróżnorodności, żyzności gleb i ich aktywności biologicznej (Kuś 2012, Smagacz 2012). W analizowanym okresie o ponad 10 p.p. spadł natomiast udział zbóż w powierzchni 


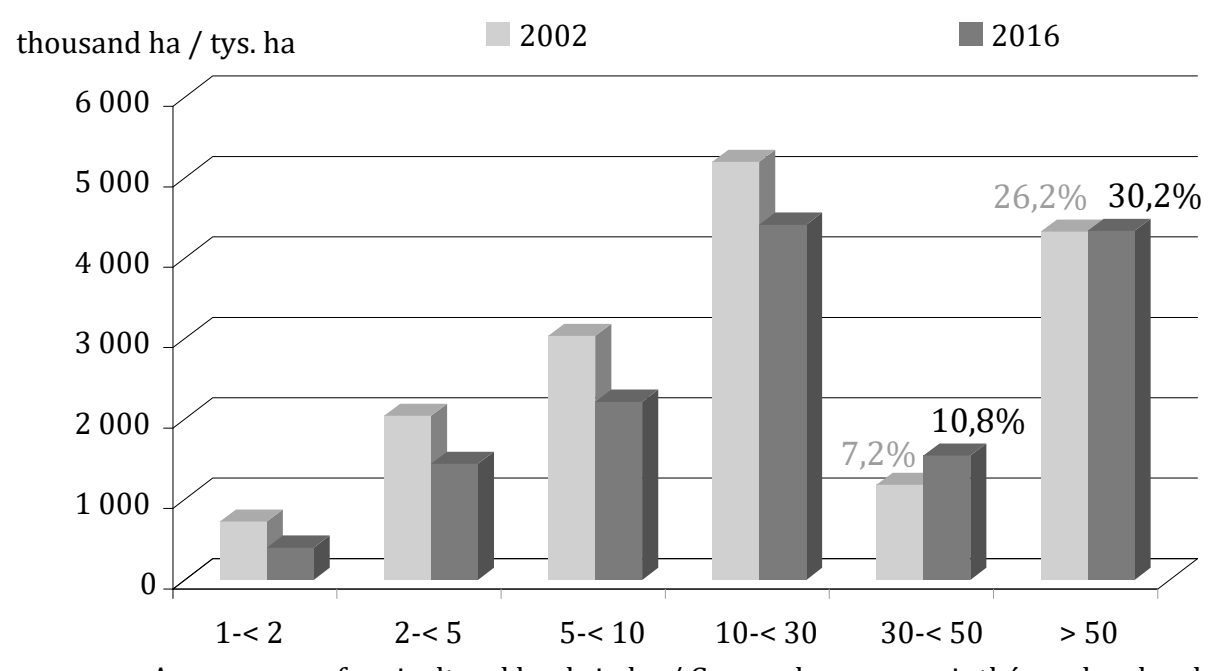

Figure 3. Concentration of the area of agricultural land* in Poland * - it applies to farms with an area exceeding 1 hectare of AL

Rysunek 3. Koncentracja powierzchni użytków rolnych*w Polsce

* - dotyczy gospodarstw o powierzchni powyżej 1 ha UR

Source: Author's own elaboration based on CSO data: Land use... (2002-2017).

Źródło: opracowanie własne na podstawie danych GUS: Użytkowanie gruntów... (2002-2017).

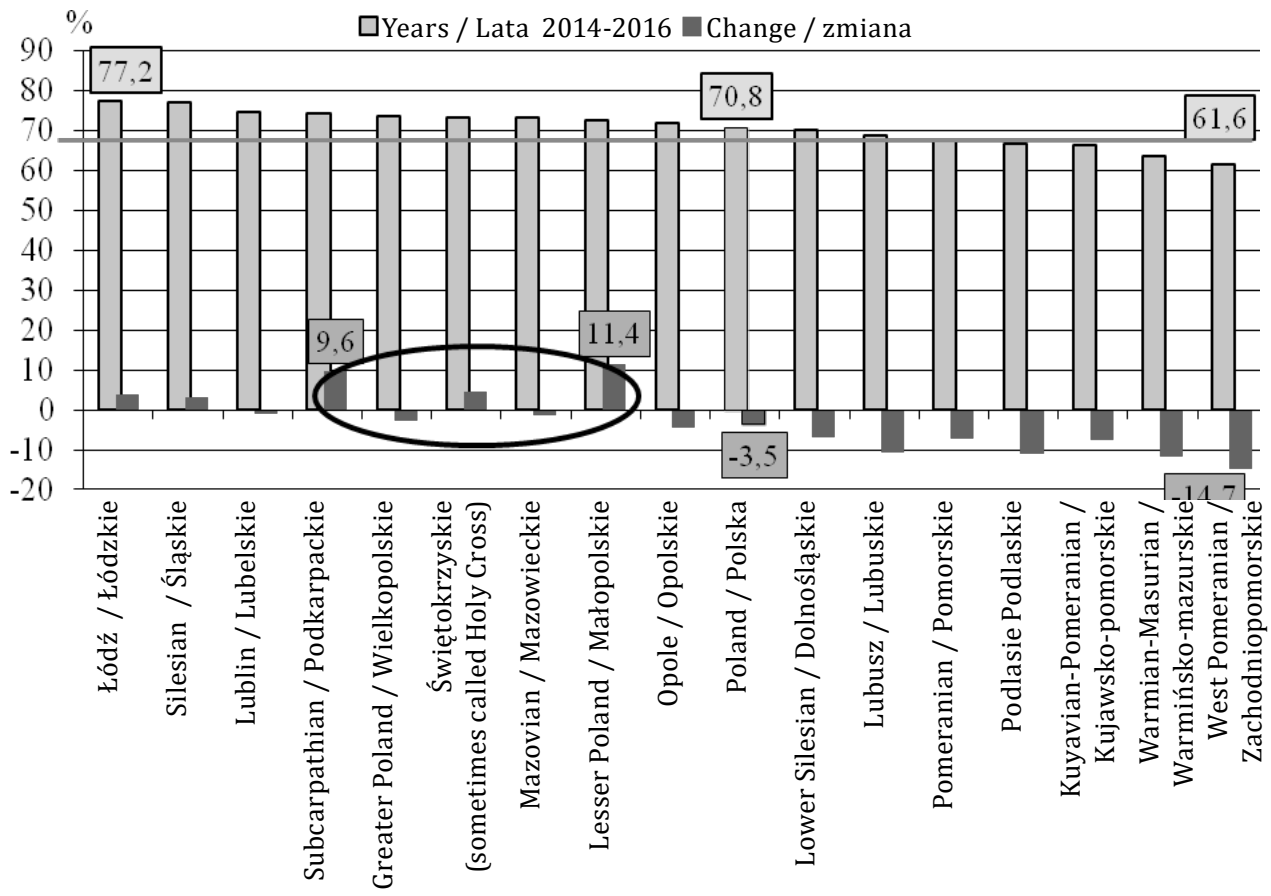

Figure 4. The share of cereals in the crop structure (\%) in selected provinces of Poland, and changes between 2001-2003 and 2014-2016

Rysunek 4. Udział zbóż w strukturze zasiewów (\%) w województwach Polski i zmiany pomiędzy latami 2001-2003 a 20142016

Source: Author's own elaboration based on CSO data: Cultivation production... (2002-2017).

Źródło: opracowanie własne na podstawie danych GUS: Produkcja upraw... (2002-2017).

Warminsko-mazurskie and Zachodniopomorskie provinces decreased by over $10 \mathrm{pp}$. In the majority of provinces in which we note a decrease in the share of cereals, we can see their supplementation with rape cultivation. The share of this plant in the zasiewów w województwach: lubuskim, podlaskim, warmińsko-mazurskim i zachodnio-pomorskim. W większości województw w których odnotowujemy zmniejszanie się udziału zbóż następowało ich subsydiowanie uprawą rzepaku. Udział tej rośliny w struk- 
crop structure of the Zachodniopomorskie province during the years 2014-2016 was approx. 17\% (Fig. 5). Since the beginning of this century, an increase in the area of rape and turnip rape sowings has been observed in all Polish provinces.

In Poland, the reverse (downward) trend occurred in the cultivation of sugar beet. The share of cultivation of this plant in the structure of sowings in relation to years 2001-2003 decreased by $0.8 \mathrm{pp}$ and now amounts to less than $2 \%$ (Fig. 6). The importance of this plant will most likely sadly decrease, due to the expected liberalisation of sugar market in Europe (Szajner 2017).

In the analysed period, i.e. 2001-2016, an even greater regression of scale and importance than in the case of sugar beet took place in potato cultivation. Its share in the crop structure decreased by more than $5 \mathrm{pp}$ and currently amounts to less than 3\% (Fig. 7). The largest decreases in the area of cultivation of this plant took place in provinces in which until now, but also now, it was quite significant (also as a plant cultivated for self-supply), i.e. in the Malopolska, Podkarpackie and Podlaskie provinces.

The growing share of legumes in the crop structure in Poland over the past dozen or so years (Fig. 8) is a confirmation of a large revival of interest in legumes (Księżak, Bojarszczuk 2016, Księżak, Kopiński 2009).

Since the beginning of the 21st century, there has been a slow but systematic upward trend in plant productivity. Compared to the years 2001-2003, plant productivity in the years 2013-2015 increased by $16 \%$ and is close to reaching 40 cereal units per ha ${ }^{-1}$ UAA (Fig. 9). According to Matyka (2014), the yields of the majority of main arable crops are generally lower than the EU-27 average and significantly lower than in Germany, indicating that Polish agriculture has not fully exploited biological, technical and organisational progress. There are also significant differences in yields of the main arable crops in individual provinces (Kopiński 2017d).

Tracking the trends and the scale of changes in mineral fertilisation is of particular importance when the focus is placed on the productivity of agricultural land, mainly crop yield, but also on possible effects of environmental impact. In Poland, the consumption of mineral fertilisers, after the turmoil associated with the political transformation, shows a steady upward trend (Matyka 2013, Kopiński 2017c). After 2000, and especially after the accession to the EU, the pace of growth accelerated markedly. Between 2001-2003 and 2013-2015 the consumption of mineral fertilisers in Poland increased on average by $41 \mathrm{~kg}$ Compound Fertilisers (which are to be henceforth understood as fertilisers containing nitrogen, phosphorus and potassium) per ha ${ }^{-1}$ UAA, i.e. by $44 \%$ (Fig. 10). The ratio of N: P: K nutrients in the applied mineral fertilisation is constantly increasing in favour of nitrogen. This is a disadvantageous trend, not only for production but also for environmental reasons, as it leads to the depletion of soil in terms of bioavailable forms of phosphorus and potassium, causing also a decrease in technical and economic efficiency (Kopiński 2017c). turze zasiewów województwa zachodnio-pomorskiego w latach 2014-2016 wynosił ok. 17\% (rys. 5). Od poczatku tego wieku we wszystkich województwach Polski odnotowano zwiększenie powierzchni zasiewów rzepaku i rzepiku.

W Polsce odwrotna tendencja (spadkowa) zachodziła w uprawie buraka cukrowego. Udział uprawy tej rośliny w strukturze zasiewów w odniesieniu do lat 2001-2003 zmniejszył się o 0,8 p.p. i obecnie stanowi niecałe $2 \%$ (rys. 6). Znaczenie tej rośliny będzie się niestety prawdopodobnie zmniejszać w związku z przewidywaną liberalizacją rynku cukru w Europie (Szajner 2017).

W analizowanym okresie, tj. 2001-2016, jeszcze większy regres skali i znaczenia, niż w przypadku buraka cukrowego, miał miejsce $\mathrm{w}$ uprawie ziemniaka. Udział tej uprawy w strukturze zasiewów zmniejszył się o ponad 5 p.p i obecnie wynosi on niecałe 3\% (rys. 7). Największe spadki powierzchni uprawy tej rośliny miały miejsce $\mathrm{w}$ województwach w których dotychczas, ale i obecnie, miała ona dość duże znaczenie (m.in. także jako roślina uprawiana na samozaopatrzenie), tj. w województwie małopolskim i podkarpackim, ale także $\mathrm{w}$ podlaskim.

Wzrastający w ostatnich kilkunastu latach udział powierzchni uprawy roślin strączkowych na nasiona w strukturze zasiewów Polski (rys. 8), jest potwierdzeniem dużego (ponownego) wzrostu zainteresowania roślinami bobowatymi (Księżak, Bojarszczuk 2016; Księżak, Kopiński 2009).

Od początku XXI mamy do czynienia z powolnym, aczkolwiek systematycznym, wzrostowym trendem produktywności roślinnej. W odniesieniu do lat 20012003 w latach 2013-2015 produktywność roślinna wzrosła o $16 \%$ i jest bliska osiągnięciu poziomu 40 j.zb.'ha-1 UR (rys. 9). Jak twierdzi Matyka (2014) plony większości głównych roślin uprawnych są na ogół niższe niż średnio w UE-27 i zdecydowanie niższe niż w Niemczech, wskazując na niewykorzystywanie w pełni przez polskie rolnictwo postępu biologicznego, technicznego i organizacyjnego. Istnieją ponadto znaczące różnice $w$ poziomie plonowania głównych roślin uprawnych w poszczególnych województwach (Kopiński 2017d).

Z punktu widzenia produktywności ziemi rolniczej, głównie roślinnej, ale także możliwych skutków oddziaływań środowiskowych, szczególnego znaczenia nabiera śledzenie trendów i skali zmian nawożenia mineralnego. W Polsce zużycie nawozów mineralnych, po zawirowaniach związanych z transformacją ustrojową, wykazuje stałą tendencję wzrostowa (Matyka 2013, Kopiński 2017c). Po roku 2000., a szczególnie po akcesji do UE, o wzrostowe tempo uległo wyraźnemu przyśpieszeniu. Pomiędzy latami 2001-2003 a 2013-2015 zużycie mineralnych nawozów w Polsce wzrosło średnio o $41 \mathrm{~kg}$ NPK·ha ${ }^{-1} \mathrm{UR}$, tj. o 44\% (rys. 10). Stosunek składników pokarmowych $\mathrm{N}: \mathrm{P}: \mathrm{K}$ w stosowanym nawożeniu mineralnym ulega stale poszerzeniu na rzecz azotu. Jest to niekorzystna tendencja, nie tylko ze względów produkcyjnych ale także środowiskowych, gdyż prowadzi do zubożenia gleby w przyswajalne formy fosforu i potasu, powodując także obniżenie efektywności technicznej 


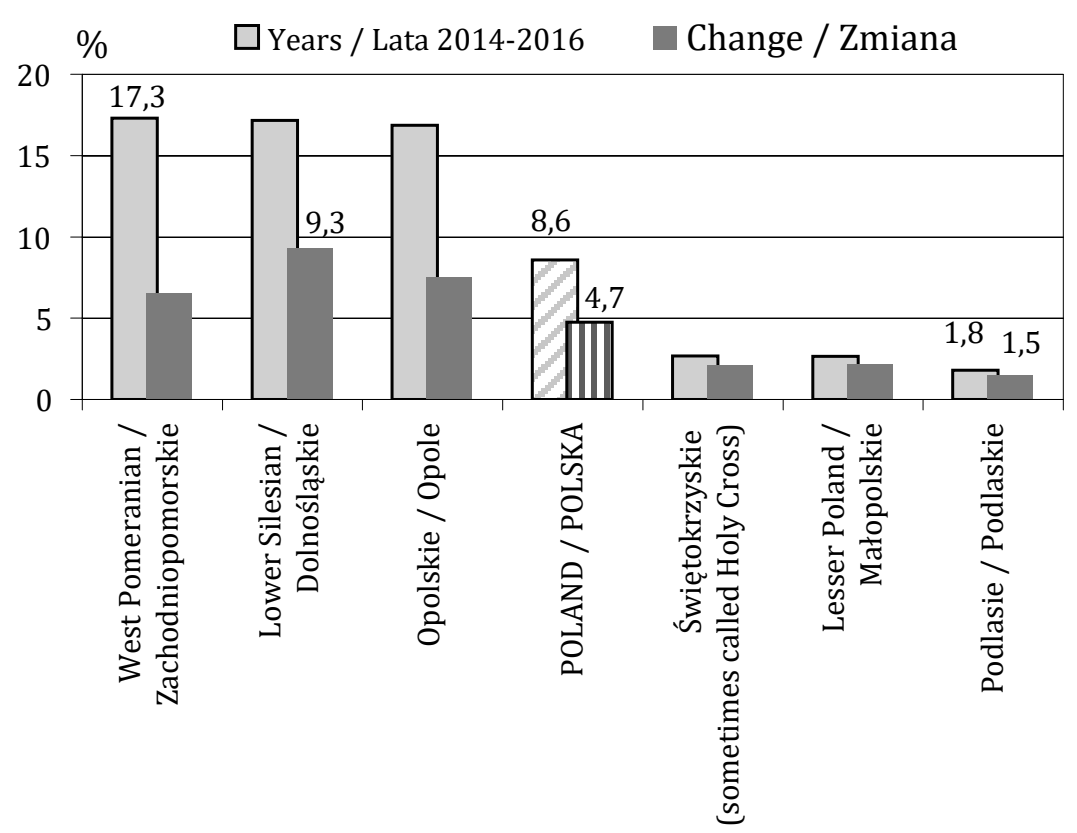

Figure 5. The share of rape and turnip rape in the crop structure (\%) in selected* provinces of Poland, and changes between 2001-2003 and 2014-2016

Rysunek 5. Udział rzepaku i rzepiku w strukturze zasiewów (\%) w wybranych* województwach Polski i zmiany pomiędzy latami 2001-2003 a 2014-2016.

* three provinces with the highest and the lowest share in the sowing structure / trzy województwa o najwyższym i najniższym udziale danej uprawy w strukturze zasiewów

Source: Author's own elaboration based on CSO data: Cultivation production... (2002-2017).

Źródło: opracowanie własne na podstawie danych GUS: Produkcja upraw... (2002-2017).

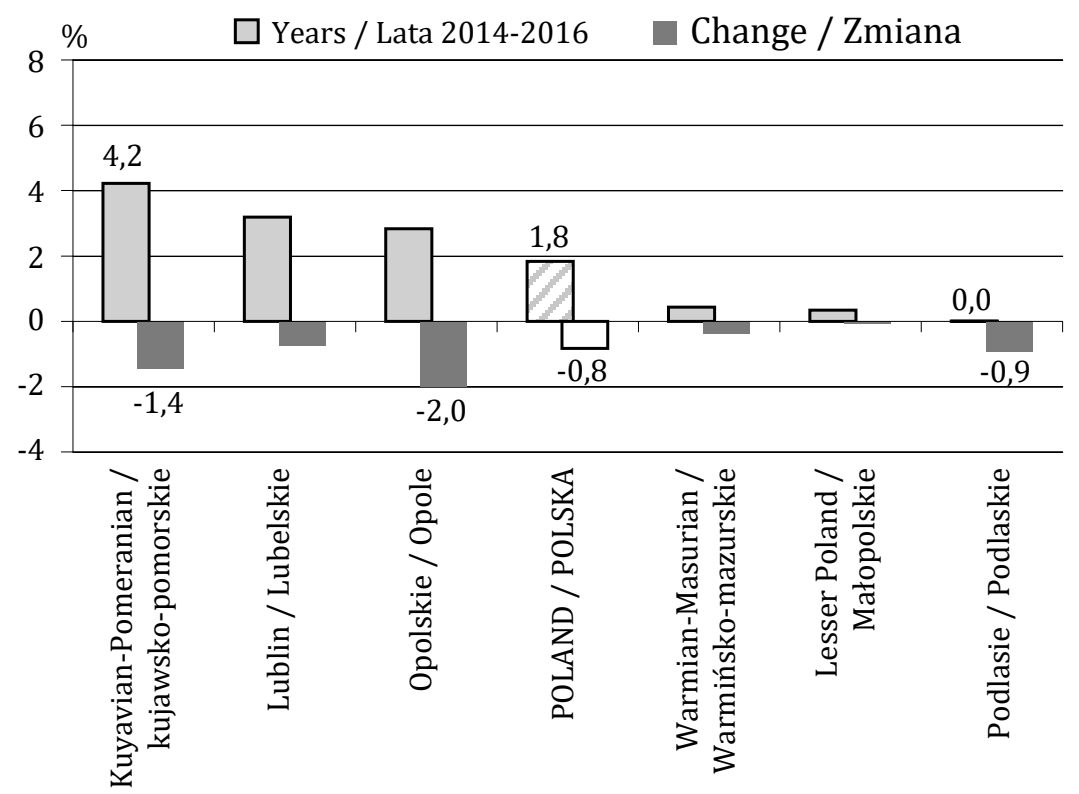

Figure 6. The share of sugar beet in the crop structure (\%) in selected* provinces of Poland, and changes between $2001-2003$ and 2014-2016

Rysunek 6. Udział buraka cukrowego w strukturze zasiewów (\%) w wybranych* województwach Polski i zmiany pomiędzy latami 2001-2003 a 2014-2016

* explanation at Fig. 5 / objaśnienie przy rys. 5

Source: Author's own elaboration based on CSO data: Cultivation production... (2002-2017).

Źródło: opracowanie własne na podstawie danych GUS: Produkcja upraw... (2002-2017). 


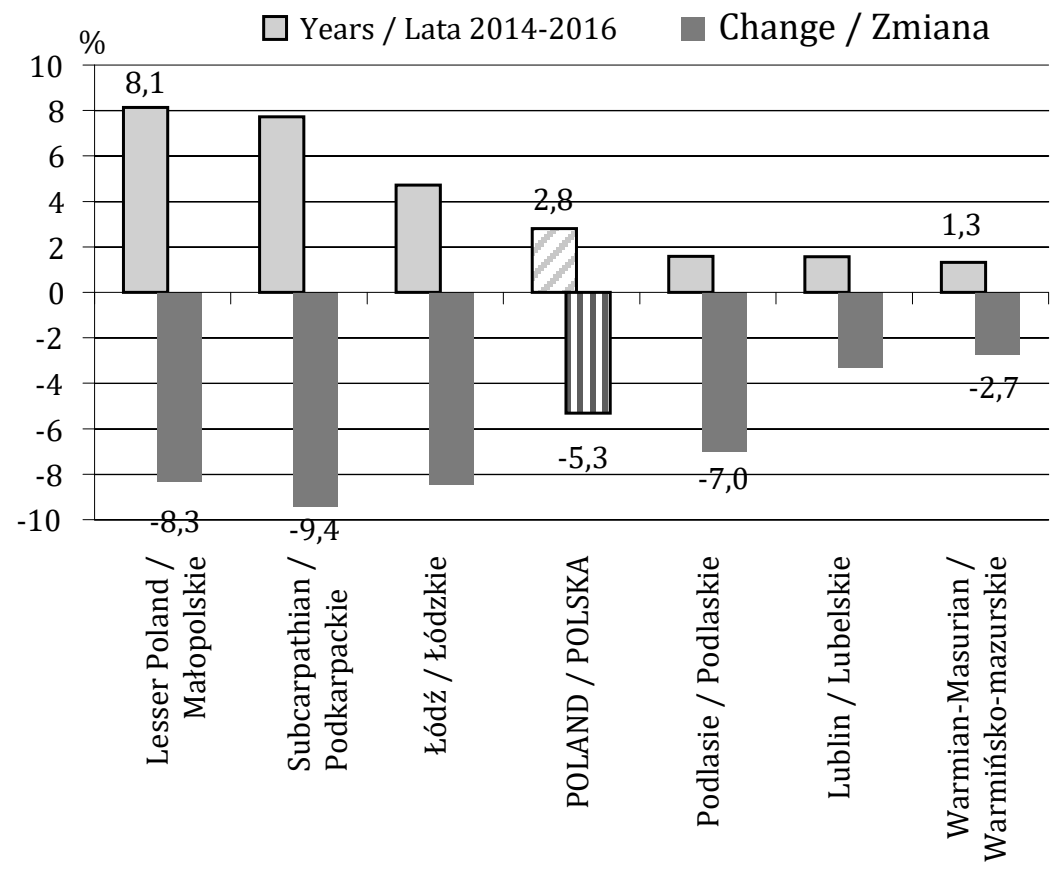

Figure 7. The share of potato in the crop structure (\%) in selected* provinces of Poland, and changes between 2001-2003 and 2014-2016

Rysunek 7. Udział ziemniaka w strukturze zasiewów (\%) w wybranych* województwach Polski i zmiany pomiędzy latami 2001-2003 a 2014-2016

* explanation at Fig. 5 / objaśnienie przy rys. 5

Source: Author's own elaboration based on CSO data: Cultivation production... (2002-2017).

Źródło: opracowanie własne na podstawie danych GUS: Produkcja upraw... (2002-2017).

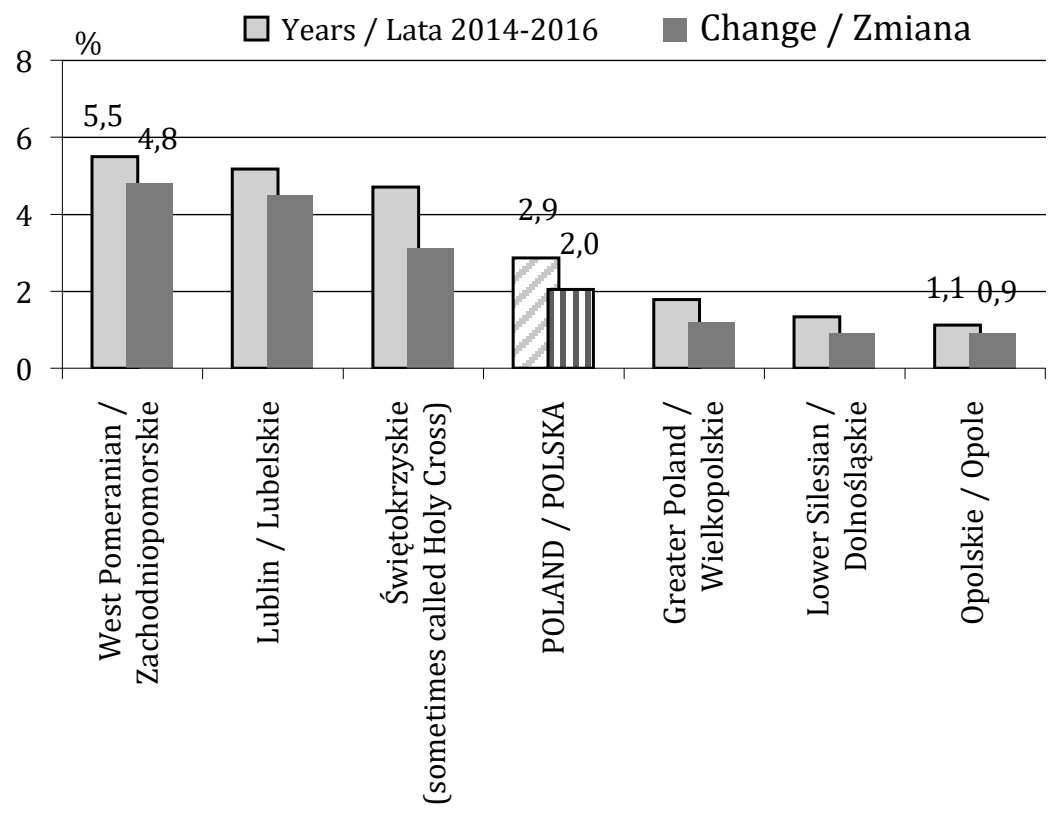

Figure 8. Percentage of legumes (peas, beans and fodder) in the crop structure (\%) in selected* provinces of Poland, and changes between 2001-2003 and 2014-2016

Rysunek 8. Udział strączkowych na nasiona (jadalne i pastewne) w strukturze zasiewów (\%) w wybranych* województwach Polski i zmiany pomiędzy latami 2001-2003 a 2014-2016

* explanation at Fig. 5 / objaśnienie przy rys. 5

Source: Author's own elaboration based on CSO data: Cultivation production... (2002-2017).

Źródło: opracowanie własne na podstawie danych GUS: Produkcja upraw... (2002-2017). 


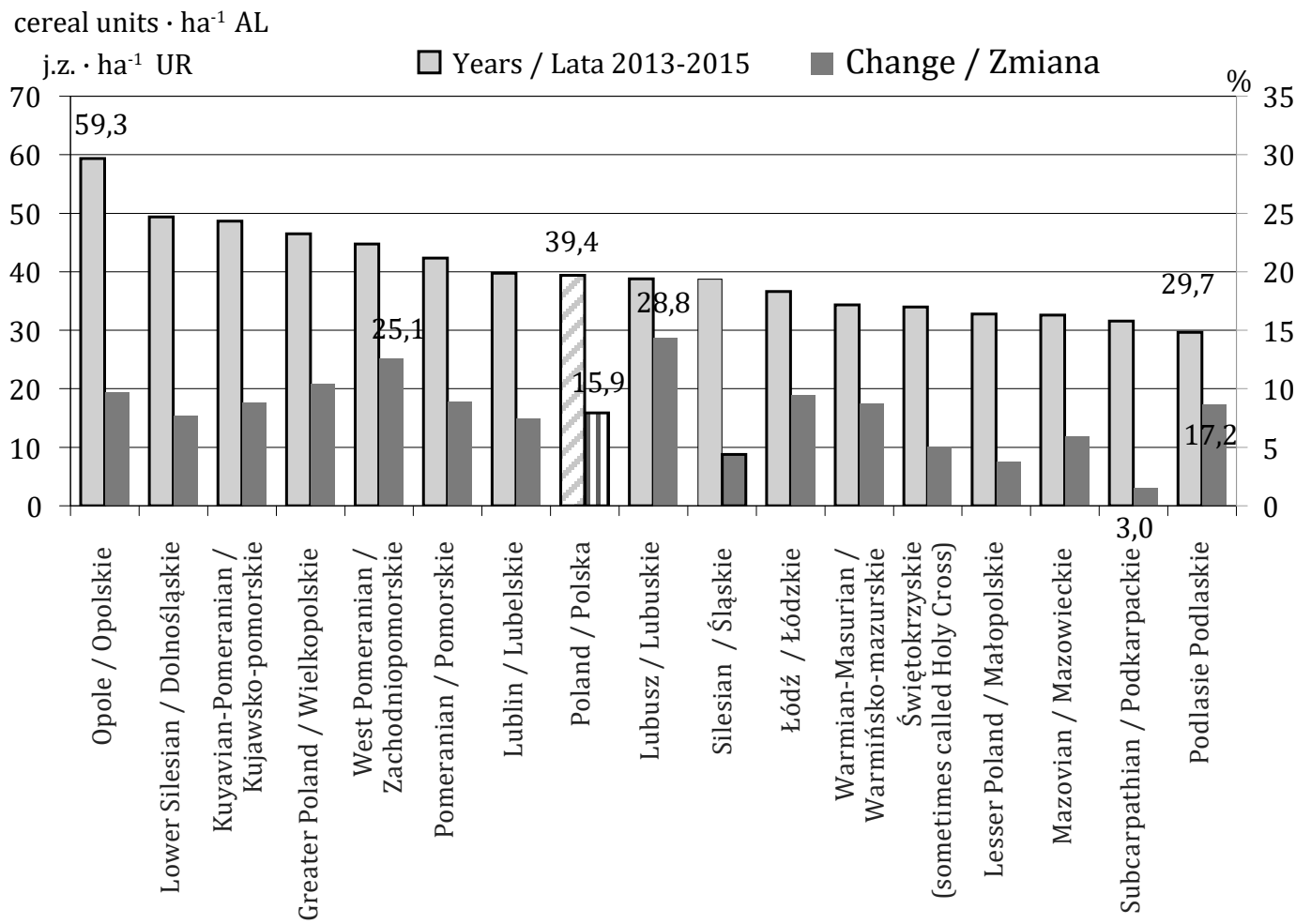

Figure 9. Crop productivity in the provinces of Poland and its changes (\%) between 2001-2003 and 2013-2015 Rysunek 9. Produktywność roślinna w województwach Polski i jej zmiany (\%) pomiędzy latami 2001-2003 a 2013-2015 Source: Author's own elaboration based on CSO data: Cultivation production... (2002-2017). Źródło: opracowanie własne na podstawie danych GU : Produkcja upraw... (2002-2017).

The degree of utilisation of nitrogen fertilisers is particularly important in the context of progressive soil acidification (Kopiński et al. 2013).

The increase in the level of mineral fertilisation with Nitrogen, Phosphorus and Potassium components in the analysed period concerned all provinces. The highest average increase in the use of mineral fertilisers (over $50 \mathrm{~kg}$ Compound Fertilisers per-ha-1 UAA) was observed in provinces with intensive plant production, i.e.: Dolnoslaskie, Opolskie, but also in Lodzkie (Fig. 10).

The consumption of Nitrogen-PhosphorusPotassium (NPK) mineral fertilisers in Malopolska Podlaskie and Warminsko-mazurskie provinces grew the slowest during the analysed period. This analysis confirms the author's previous conclusions concerning the deepening polarisation of production intensity in Polish agriculture (Kopiński 2013), and, due to the significant dependence on the final balance of these components (Jurga, Kopiński 2016), it significantly determines the pressure exerted on the environment.

Another important measure of the agricultural production intensity is the stocking density of the livestock. During the years 2014-2016, the average stocking density of livestock in Poland was $46.9 \mathrm{LU}$ per $100 \mathrm{ha}^{-1} \mathrm{UAA}$, and in relative terms it decreased by $11 \%$ compared to $2001-2003$ (Fig. 11). Since the beginning of the 21st century, including the period of Poland's membership in the EU, the situation in animal production in Poland has been relatively stable, if its assessment is limited only to the stocking i ekonomicznej (Kopiński 2017c). Stopień wykorzystania nawozów azotowych jest istotny szczególnie w kontekście postępującego zakwaszenia gleb (Kopiński i in. 2013).

Wzrost poziomu nawożenia mineralnego składnikami NPK w analizowanym okresie dotyczył wszystkich województw. Największy średni przyrost zużycia nawozów mineralnych (powyżej $50 \mathrm{~kg} \mathrm{NPK} \cdot \mathrm{ha}^{-1}$ UR) występował $\mathrm{w}$ województwach o intensywnej produkcji roślinnej, tj.: dolnośląskim, opolskim, ale także w łódzkim (rys. 10).

Najwolniej w analizowanym okresie wzrastało zużycie nawozów mineralnych NPK w województwach małopolskim, podlaskim i warmińsko-mazurskim. Analiza ta potwierdza wcześniejsze wnioski autora mówiące o pogłębiającej się polaryzacji intensywności produkcji w polskim rolnictwie (Kopiński 2013), a ze względu na istotną zależność z końcowym saldem bilansów tych składników (Jurga, Kopiński 2016), w znaczącym stopniu decyduje o sile presji wywieranej na środowisko.

Inną ważną miarą intensywności produkcji rolniczej jest obsada zwierząt. W latach 2014-2016 obsada zwierząt w Polsce wynosiła średnio 46,9 DJP.100 ha $^{-1}$ UR, a w ujęciu względnym zmniejszyło się o $11 \%$ w porównaniu do lat 2001-2003 (rys. 11). Od początku XXI w., w tym w okresie członkostwa Polski w UE, sytuacja w produkcji zwierzęcej w Polsce jest względnie stabilna, jeżeli jej ocenę ograniczymy tylko do wskaźnika obsady. 0 dynamicznie zmieniającej się sytuacji w tym dziale produkcji świadczą zmiany pogłowia poszczególnych grup uży tkowych zwierząt 


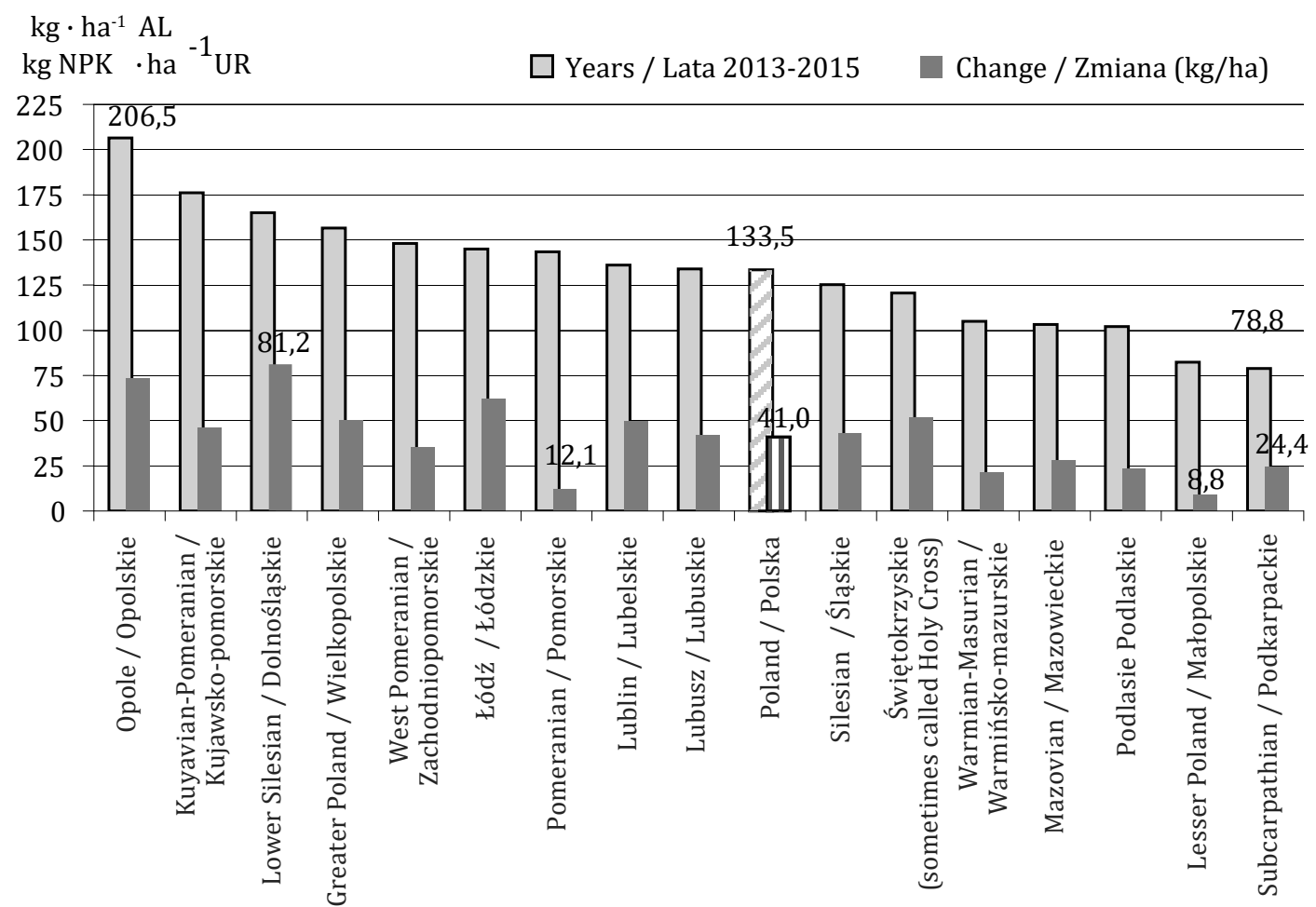

Figure 10. Consumption of Nitrogen, Phosphorus and Potassium compounds in mineral fertilisers in Poland, and changes (kg per ha' ${ }^{-1}$ ) between 2001-2003 and 2013-2015

Rysunek 10. Zużycie składników NPK w nawozach mineralnych w Polsce i zmiany (kg·ha-1) pomiędzy latami 2001-2003 a 20132015

Source: Author's own elaboration based on CSO data; Means of production... (2000-2016).

Źródło: opracowanie własne na podstawie danych GUS; Środki produkcji... (2000-2016).

density index. The dynamically changing situation in this production department is evidenced by changes in the number of individual animal production groups (Kopiński 2017a) and changes occurring in individual regions of the country (NUTS-2) (Fig. 11).

In Poland, the differences in animal husbandry are deepening, leading to increased production polarisation (Kopiński 2014a). Between 2001-2003 and 2014-2016, the livestock density in the Lubelskie, Malopolskie, Podkarpackie and Swietokrzyskie provinces has decreased by over 35\% (Fig. 11), forming the "Małopolska i Pogorze" region according to the FADN division (Kopiński et al. 2010). It can be said that the provinces of this "region" are heading towards non-livestock agricultural production, which is characteristic of the Dolnoslaskie and Opolskie or Zachodniopomorskie provinces. In this respect, the distance between these groups of voivodships is significantly reduced (Kopiński 2017c).

The consequences of changes in animal production are multi-faceted, which also affects environmental changes. Reducing the level of fertilisation with natural fertilisers, also due to the increased importance of the slatted system of livestock rearing, will lead to a decrease in the content of organic matter in the soil and then to the deterioration of soil fertility (Kopiński, Kuś 2011). In animal production, the organisation of production is extensified (specialisation) with the simultaneous increase in its intensity (concentration), which may result in
(Kopiński 2017a) i zmiany zachodzące w poszczególnych regionach kraju (NUTS-2) (rys. 11).

W Polsce w chowie zwierząt następuje pogłębienie różnic pomiędzy poszczególnymi województwami, prowadząc do wzrostu polaryzacji produkcji (Kopiński 2014a). Pomiędzy latami 2001-2003 a 2014-2016 obsada zwierząt inwentarskich w województwach: lubelskim, małopolskim, podkarpackim i świętokrzyskim zmniejszyła się ponad 35\% (rys. 11), tworzących razem region „Małopolska i Pogórze” wg podziału FADN (Kopiński i in. 2010). Można powiedzieć, że województwa tego „regionu” zmierzają w kierunku prowadzenia bezinwentarzowej produkcji rolniczej, która jest charakterystyczna dla województw dolnośląskiego i opolskiego czy zachodniopomorskiego. W tym względzie dystans pomiędzy tymi grupami województw ulega wyraźnemu zmniejszeniu (Kopiński 2017c).

Konsekwencje zmian w produkcji zwierzęcej sa wieloaspektowe i wielopłaszczyznowe, rzutując także na zmiany stanu środowiska. Obniżenie poziomu nawożenia nawozami naturalnymi, także ze względu na wzrost znaczenia rusztowego systemu utrzymania zwierząt prowadzić będzie do obniżenia zawartości glebowej substancji organicznej, a następnie pogorszeniem żyzności gleb (Kopiński, Kuś 2011). W produkcji zwierzęcej następuje ekstensyfikacja organizacji produkcji (specjalizacja) z jednoczesnym wzrostem jej intensywności (koncentracja), wynikiem czego może być wzrost presji środowiskowej na 


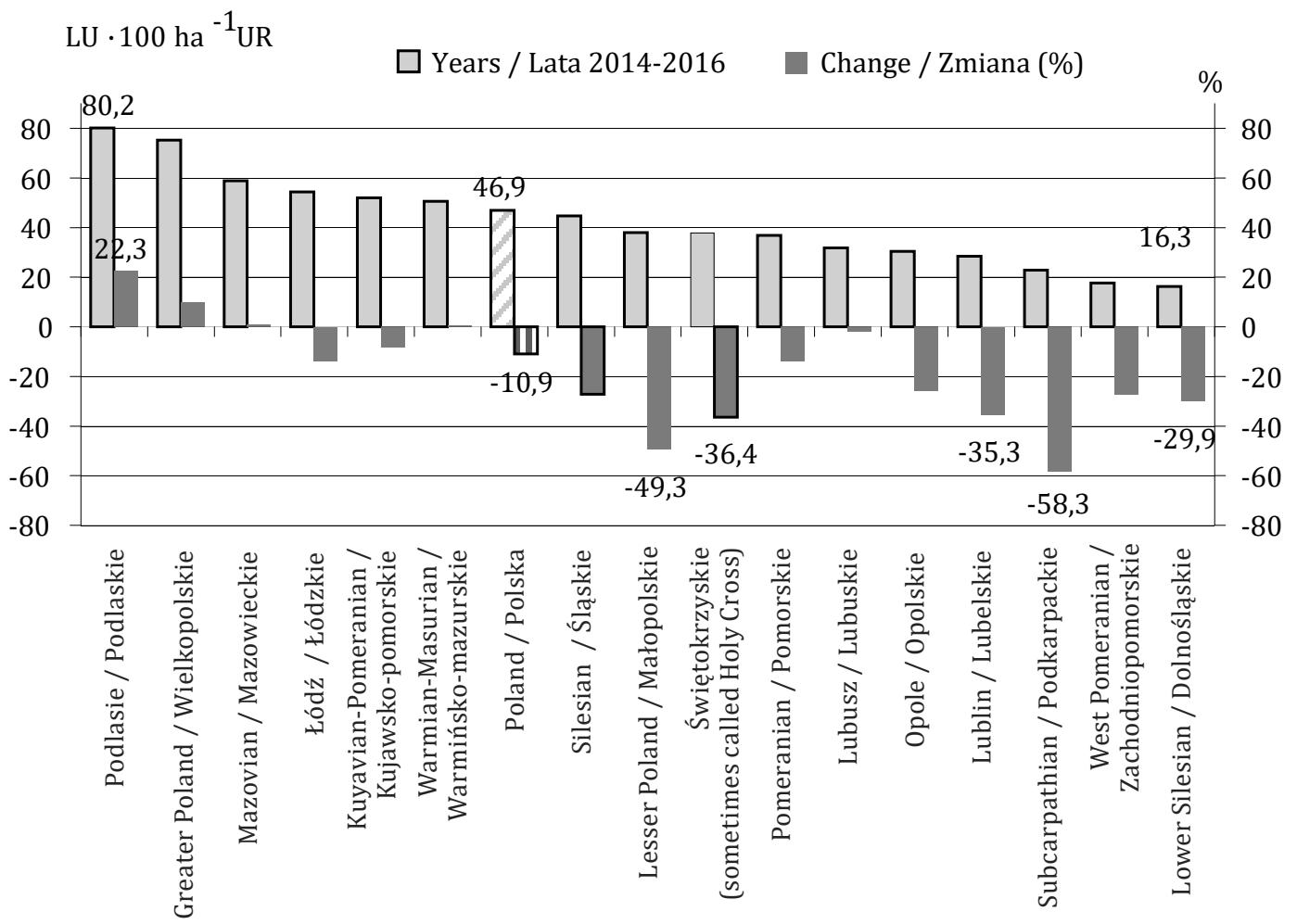

Figure 11. Animal stocking density in provinces of Poland, and its changes (\%) between 2001-2003 and 2014-2016 Rysunek 11. Obsada zwierząt w województwach Polski i jej zmiany (\%) pomiędzy latami 2001-2003 a 2014-2016 Source: Author's own elaboration based on CSO data: Land use... (2000-2012); Farm animals (2013-2017). Źródło: opracowanie własne na podstawie danych GUS: Użytkowanie gruntów... (2000-2012); Zwierzęta gospodarskie (20132017).

increased environmental pressure in areas with high concentration of livestock production (Kopiński 2014b), leading to, among others, deterioration of surface and ground water quality (Fotyma et al. 2010).

The most important agro-environmental indicators, which provide information on the correct management of fertiliser components and possible environmental effects, include balances of mineral components (Jadczyszyn, Kopiński 2013, Kopiński 2010, 2017a, 2017c). The loss of fertiliser components occurs during harvesting of plants or during grazing. Some of the compounds are released from the circuit into the hydrosphere and atmosphere, as well as into the human nutrition cycle. Leaving soils without vegetation, especially in the conditions of high rainfall and low temperatures, also contributes to certain losses (Kopiński 2017a).

The gross balance of nitrogen in Poland in 2013-2015 compared to the period 2002-2004 remained unchanged and amounted to an average of $47.5 \mathrm{~kg} \mathrm{~N}$ per ha ${ }^{-1}$ UAA (Fig. 12). Its changes were strongly influenced by changes in the level of mineral fertilisation with nitrogen. As a result of the quantitative and structural changes of individual elements of both sides of the gross nitrogen balance, there is a slight increase in the efficiency of the use of this component (Kopiński 2017c). In the analysed period, this increase concerned all provinces of Poland, with the exception of Dolnoslaskie province. In the analysed period, apart from the Dolnoslaskie voivodships, the following provinces obszarach o dużej koncentracji produkcji zwierzęcej (Kopiński 2014b), prowadząc m.in. do pogorszenia jakości wód powierzchniowych i gruntowych (Fotyma i in. 2010).

Do najważniejszych wskaźników agro-środowiskowych, informujących o poprawności gospodarowania składnikami nawozowymi i możliwych skutkach środowiskowych należą salda bilansów składników mineralnych (Jadczyszyn, Kopiński 2013; Kopiński 2010; 2017a; 2017c). Do strat składników nawozowych dochodzi podczas zbioru roślin czy podczas wypasu zwierząt. Część związków wydostaje się z obiegu do hydrosfery i atmosfery, a także do obiegu odżywiania człowieka. Do pewnych strat przyczynia się również pozostawianie gleb bez okrycia roślinnością, szczególnie $\mathrm{w}$ warunkach dużych opadów i niskich temperatur (Kopiński 2017a).

Saldo bilansu azotu brutto $\mathrm{w}$ Polsce $\mathrm{w}$ latach 2013-2015 w porównaniu do okresu lat 2002-2004 nie uległo zmianie i wynosiło średnio $47,5 \mathrm{~kg}$ N·ha ${ }^{1}$ UR (rys. 12). Na jego zmiany silny wpływ miały zmiany poziomu nawożenia mineralnego azotem. Efektem zmian ilościowych i strukturalnych poszczególnych elementów obu stron bilansu azotu brutto jest niewielki wzrost efektywności wykorzystania tego składnika (Kopiński 2017c). W analizowanym okresie wzrost ten dotyczył wszystkich województw Polski, z wyjątkiem dolnośląskiego. W analizowanym okresie największymi zmianami salda bilansu i efektywności wykorzystania azotu, poza województwem dolnośląskim, wyróżniały się 
were distinguished in terms of the largest changes in the balance and effectiveness of nitrogen utilisation: Lubuskie, Zachodniopomorskie, Malopolskie and Podkarpackie (Fig. 12).

The strongly regionally differentiated balances of nitrogen, as well as its individual elements, show the potential scale of diversification of agriculture's influence on the state of the environment. Over the last few years, very large surpluses of nitrogen balance have occurred in the Kujawsko-pomorskie, Lodzkieand Wielkopolskie provinces, where high pressure on the environment due to excess of nitrogen is to be expected (Fig. 12). The overruns of optimum balances designated for these provinces are quite significant (Kopiński, 2015; Kopiński, 2017b). For various reasons, the significant amounts of nitrogen in these provinces are not effectively used (Kopiński, 2017c). The implication of this assessment may be aggravated by the fact that this area has a large share of light soils with a smaller water capacity, which are more exposed to lessivage (Fotyma et al. 2010).

In the last 11 years, the significant reduction in terms of quantity of the grossvalue of nitrogen balances occurred in the following provinces: Lubuskie, województwa: lubuskie, zachodniopomorskie, małopolskie i podkarpackie (rys. 12).

Silnie zróżnicowane regionalnie sald bilansu azotu jak i jego poszczególnych elementów pokazują potencjalną skalę zróżnicowania oddziaływania rolnictwa na stan środowiska. W ostatnich latach bardzo duże nadwyżki bilansowe azotu występują w województwach kujawsko-pomorskim, łódzkim i wielkopolskim, w których należy oczekiwać dużej presji na środowisko ze strony nadmiaru azotu (rys. 12). Przekroczenia wyznaczone dla tych województw optima sald są dość znaczne (Kopiński 2015; Kopiński 2017 b). Z różnych powodów znaczne ilości azotu w tych województwach nie są efektywnie wykorzystywane (Kopiński 2017c). Wymowę tej oceny może pogarszać fakt, że obszar ten ma duży udział gleb lekkich o mniejszej pojemności wodnej, które są bardziej narażone na procesy przemywania (Fotyma i in. 2010).

W ciągu ostatnich 11. lat do ilościowo znacznej redukcji sald azotu brutto doszło $\mathrm{w}$ województwach: lubuskim, małopolskim, zachodniopomorskim i podkarpackim. Przyczyny tego zjawiska wynikają z poprawy plonowania roślin (zachodniopomorskie) lub

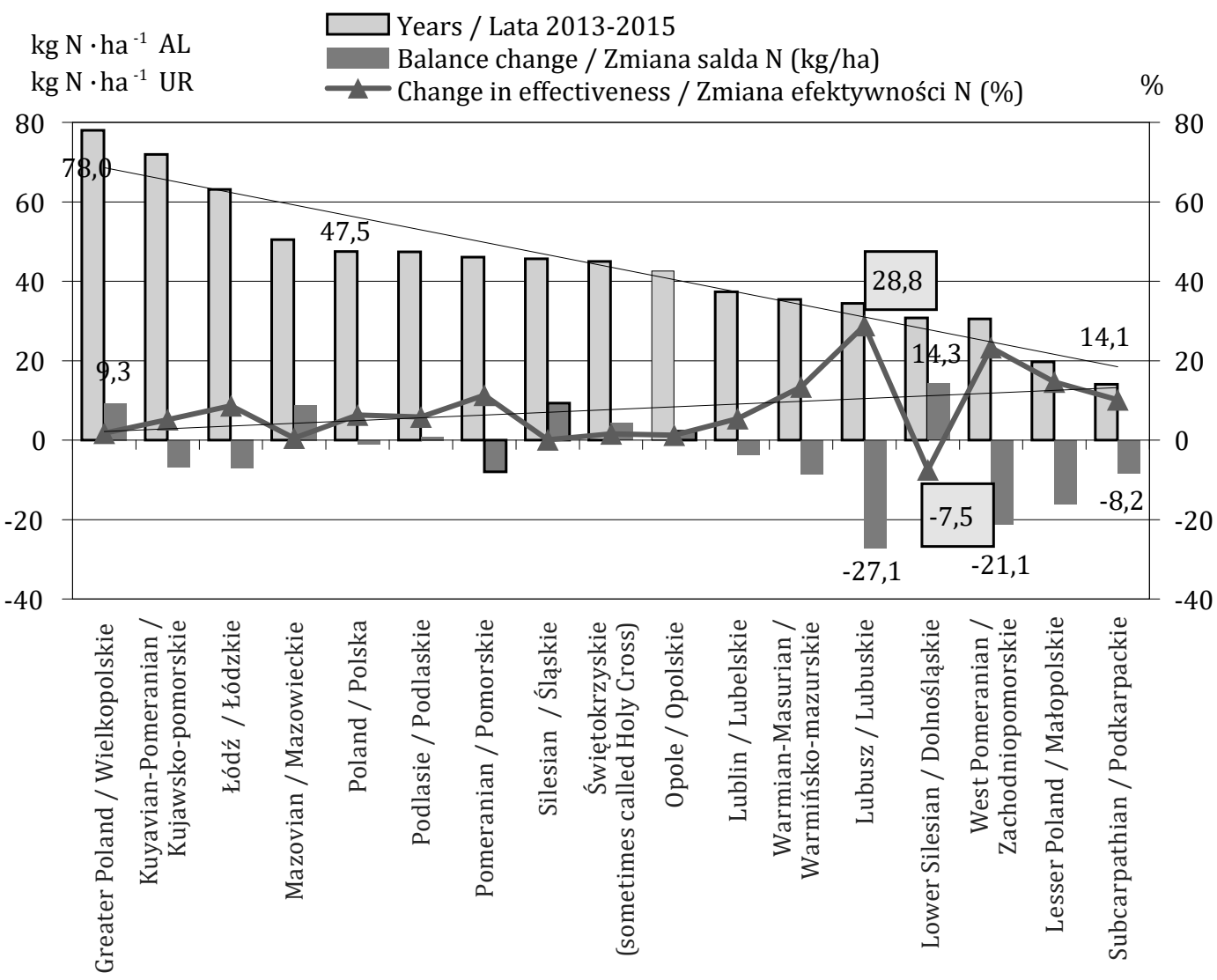

Figure 12. Gross nitrogen balance* in Polish provinces and its changes between 2002 and 2004, and also between 2013 and 2015.

Rysunek 12. Saldo bilansu azotu brutto* w województwach Polski i jego zmiany pomiędzy okresem lat 2002-2004 a 2013-2015.

* Source: Methodology based on Environmental Indicators for Agriculture. Publications Service. OECD, Paris, 2006, vol. 4, chapter 3 and Kopiński (2017a) / Źródło: Metodyka na podstawie Environmental Indicators for Agriculture. Publications Service. OECD, Paris, 2006, vol. 4, chapter 3 oraz Kopiński (2017a)

Source: Author's own elaboration.

Źródło: opracowanie własne. 
Malopolskie, Zachodniopomorskie and Podkarpackie. The reasons for this phenomenon result from the improvement of crop yield (Zachodniopomorskie) or from the development of the extensification of plant (as well as animal) production (in Malopolskie and Podkarpackie provinces) (Jurga, Kopiński, 2016).

The analysis of the impact of agriculture in various provinces on the environment, on the basis of this agricultural and environmental indicator, points to further deepening of regional differences in terms of organization and production, and the environment, which result from the escalating processes of specialization and concentration of agricultural production leading to polarisation at the level of provinces (Kopiński, 2013; 2015; 2017c).

\section{Conclusions}

Significant resources of agricultural area in Poland, which is the basic factor in production, have been constantly decreasing since the beginning of the 21st century. Since 2000, the cropland has decreased by nearly 4 million ha on a country scale, and in 2016 amounted to 14.5 million ha. The loss rate of the land used for agriculture is not uniform in all provinces. In the years 2002-2016, the cropland decreased by over $20 \%$, which had been the highest extent so far, in the provinces hitherto characterised by the extensive nature of agricultural production, i.e. Slaskie, Malopolskie, Podkarpackie and Swietokrzyskie. Such a significant loss of agricultural area, apart from a serious restriction of the production potential of agriculture in these regions, may also have a negative impact on the level of agricultural production and food safety in the country.

Another clearly visible and simultaneously occurring phenomenon is the process of concentration of land in larger farms. In the recent years, this process was the fastest in provinces with a land-intensive type of production intensification, i.e.: Zachodniopomorskie, Opolskie, Lubuskie and Dolnoslaskie.

Diversified organizational and economic conditions influenced the changes in the structure of sowing occurring in the years between 2001 and 2016. In most provinces cereals cultivation had its share in the crop structure decreased in favour of an increased share of rapeseed cultivation. In Poland, in the analysed years, the potato and sugar beet crops were decreasing. Confirmation of a large (re-) increase of the interest in legume plants is their growing share in the crop structure.

Compared to the years 2001-2003, plant productivity in the years 2013-2015 was increased by $16 \%$ and is close to reaching 40 cereal units'ha ${ }^{-1}$ of cropland. This trend, positive in the context of the environmental impact assessment, should be positively received. However, its growth rate is too low compared to the significant increase in production intensity. Meanwhile, the consumption of mineral fertilisers in Poland increased on average by as much as $41 \mathrm{~kg}$ Compound Fertilisers per ha ${ }^{-1}$ of cropland, i.e. by $44 \%$. The highest average increase in the use of z pogłębienia ekstensyfikacji produkcji roślinnej (ale i zwierzęcej) (w Małopolsce i Podkarpaciu) (Jurga, Kopiński 2016).

Analiza oddziaływania na środowisko rolnictwa różnych województw, na podstawie tego wskaźnika agro-środowiskowego, wskazuje na dalsze pogłębianie się różnic regionalnych pod względem organizacyjno-produkcyjnym i środowiskowym, wynikających z nasilających się procesów specjalizacji i koncentracji produkcji rolniczej, prowadząc do polaryzacji na poziomie województw (Kopiński 2013; 2015; 2017c).

\section{Podsumowanie}

Znaczne zasoby ziemi uprawnej w Polsce, będącej podstawowym czynnikiem produkcji, od początku XXI w. ulegają ciągłemu kurczeniu. Od 2000 r. powierzchnia UR w skali kraju zmniejszyła się blisko o $4 \mathrm{mln}$ ha i w 2016 r. wynosiła 14,5 mln ha. Tempo ubytku ziemi użytkowanej rolniczo nie jednakowe we wszystkich województwach. W okresie lat 20022016 powierzchnia użytków rolnych, w największym stopniu bo o ponad $20 \%$, zmniejszyła się w województwach charakteryzujących się dotychczas ekstensywnym charakterem produkcji rolniczej, tj. śląskim, małopolskim, podkarpackim, świętokrzyskim. Tak znaczny ubytek powierzchni użytkowanej rolniczo, poza poważnym ograniczeniem potencjału produkcyjnego rolnictwa tych regionów, może także wywierając negatywny wpływ na poziom produkcji rolniczej i bezpieczeństwo żywnościowe w kraju.

Innym wyraźnie widocznym, zachodzącym jednocześnie zjawiskiem jest proces koncentracji ziemi w gospodarstwach większych obszarowo. Najszybciej proces ten następował $w$ ostatnich latach $w$ województwach o ziemiochłonnym typie intensyfikacji produkcji, tj.: zachodniopomorskim, opolskim, lubuskim i dolnośląskim.

Zróżnicowane uwarunkowania organizacyjno -ekonomiczne miały wpływ na zmiany struktury zasiewów zachodzące w latach 2001-2016. W uprawie zbóż w większości województw następowało zmniejszanie się ich udziału w strukturze zasiewów, na korzyść większego udziału uprawy rzepaku. W Polsce $\mathrm{w}$ analizowanych latach w wyraźnym trendzie spadkowym znajdowały się uprawy: ziemniaka i buraka cukrowego. Potwierdzeniem dużego (ponownego) wzrostu zainteresowania roślinami bobowatymi jest rosnacy udział tych upraw w strukturze zasiewów.

W odniesieniu do lat 2001-2003 w latach 20132015 produkcyjność roślinna wzrosła o $16 \%$ i jest bliska osiągnięciu poziomu $40 \mathrm{j} . z \mathrm{zb} \cdot \mathrm{ha}^{-1} \mathrm{UR}$. Ten, pozytywny w kontekście oceny oddziaływań środowiskowych, trend należy odbierać pozytywnie, aczkolwiek jego dynamika wzrostowa jest jednak zbyt niska względem znaczącego wzrost intensywności produkcji. W tym czasie zużycie mineralnych nawozów w Polsce wzrosło bowiem średnio aż o $41 \mathrm{~kg} \mathrm{NPK} \cdot \mathrm{ha}^{-1}$ UR, tj. o 44\%. Największy średni przyrost zużycia 
mineral fertilisers (over $50 \mathrm{~kg}$ Compound Fertilisers per ha ${ }^{-1}$ cropland) was observed in provinces with intensive plant production, i.e.: Dolnoslaskie, Opolskie, but also in Lodzkie.

The dynamically changing situation in the animal production department is confirmed by changes in the headage of useful groups animal and changes occurring in individual regions of the country. In the Polish we showing increasing polarisation of animal production between individual provinces. Generally, in animal production, the organization of production is extensified (specialization) with the simultaneous increase in its intensity (concentration), which may result in increased environmental pressure in areas with high concentration of production.

The gross balance of nitrogen in Poland, as an important agrienvironmental indicator, did not change during the years between 2013 and 2015 compared to the years 2002-2004 and amounted to an average of $47.5 \mathrm{~kg} \mathrm{~N}$ per ha ${ }^{-1}$ utilized agricultural area. The strongly, regionally differentiated balances of nitrogen, as well as their individual elements, show the potential differentiation scale of the agricultural impact on the state of the environment. Over the last few years, very large surpluses of nitrogen balance have occurred in the Kujawsko-pomorskie, Lodzkie and Wielkopolskie voivodships, in which a lot of pressure on the environment due to excess of nitrogen should be expected. nawozów mineralnych (powyżej $50 \mathrm{~kg}$ NPK·ha ${ }^{-1} \mathrm{UR}$ ) występował $\mathrm{w}$ województwach o intensywnej produkcji roślinnej, tj.: dolnośląskim, opolskim, ale także w województwie łódzkim.

0 dynamicznie zmieniającej się sytuacji $\mathrm{w}$ dziale produkcji zwierzęcej świadczą zmiany pogłowia grup użytkowych zwierząt i zmiany zachodzace w poszczególnych regionach kraju. W Polsce w chowie zwierząt następuje coraz większa polaryzacja produkcji pomiędzy poszczególnymi województwami. Generalnie w produkcji zwierzęcej następuje ekstensyfikacja organizacji produkcji (specjalizacja) $\mathrm{z}$ jednoczesnym wzrostem jej intensywności (koncentracja), wynikiem czego może być wzrost presji środowiskowej na obszarach o dużej koncentracji produkcji.

Saldo bilansu azotu brutto w Polsce, jako ważnego wskaźnika agro-środowiskowego, w latach 2013$2015 \mathrm{w}$ porównaniu do okresu lat 2002-2004 nie uległo zmianie i wynosiło średnio 47,5 kg N·ha ${ }^{-1} \mathrm{UR}$. Silnie zróżnicowane regionalnie sald bilansu azotu jak i jego poszczególnych elementów pokazuja potencjalną skalę zróżnicowania oddziaływania rolnictwa na stan środowiska. W ostatnich latach bardzo duże nadwyżki bilansowe azotu wystepują w województwach kujawsko-pomorskim, łódzkim i wielkopolskim, w których należy oczekiwać dużej presji na środowisko ze strony nadmiaru azotu

\section{References / Literatura:}

1. Environmental Indicators for Agriculture (2006), Publications Service, OECD, Paris, vol. 4, chapter 3.

2. Fotyma M., Igras J., Kopiński J., Podyma W. (2010), Ocena zagrożeń nadmiarem azotu pochodzenia rolniczego w Polsce na tle innych krajów europejskich. Studia i Raporty IUNG-PIB, 20, s. 53-75.

3. Goraj L. (2000), Sieć danych rachunkowości gospodarstw rolnych w Unii Europejskiej (FADN). FAPA, Warszawa.

4. Harasim A. (2006), Przewodnik ekonomiczno-rolniczy w zarysie. IUNG-PIB Puławy.

5. Jadczyszyn T, Kopiński J. (2013), Nawożenie azotem w Polsce - aspekt produkcyjny i środowiskowy. Studia i Raporty IUNG-PIB, z. 34(8), s. 125-143

6. Józwiak W. (2013), Warunki gospodarowania oraz zmiany zachodzq̨ce w rolnictwie w latach 1989-2010, W: W. Józwiak, W. Ziętara (red.), Zmiany zachodzace w gospodarstwach rolnych w latach 2002-2010. PSR 2010, Warszawa, s. 7-23.

7. Józwiak W., Mirkowska Z. (2011), Trendy w rolnictwie polskim (lata 1990-2009) i próba projekcji na 2013 rok, W: Procesy zachodzace w rolnictwie polskim w latach 1990-2010, projekcje na rok 2013 i pożądana wizja rolnictwa w 2020 roku -zagadnienia wybrane, IERiGŻ-PIB (PW 2011-2014), Warszawa, 21, s. 9-31.

8. Jurga B., Kopiński J. (2016), Bilanse azotu i fosforu jako wskaźniki oddziaływania rolnictwa na środowisko. Studia i Raporty IUNG-PIB, nr 47(21), s. 25-38.

9. Kopiński J. (2015), Agri-environmental effects of changes in agricultural production in Poland/Agrośrodowiskowe skutki zmian produkcji rolniczej w Polsce. Economic and Regional Studies, 8(3), s. 5-18.

10. Kopiński J. (2010), Bilans azotu brutto, jako agrośrodowiskowy wskaźnik zmian intensywności produkcji rolniczej w Polsce. Zesz. Probl. Post. Nauk Rol., Olsztyn, z. 547, s. 185-191.

11. Kopiński J. (2017a), Bilans azotu brutto, jako agrośrodowiskowy wskaźnik zmian oddziaływania produkcji rolniczej na środowisko. Metodologia, wyniki bilansu na poziomie NUTS-0, NUTS-2. Monografie i rozprawy naukowe IUNG-PIB, Puławy, (w druku)

12. Kopiński J. (2017b), Metoda określenia sald bilansów NPK oraz zakresu ich bezpieczeństwa dla środowiska przyrodniczego. Ekspertyza na potrzeby IERiGŻ-PIB, Puławy, (mat. niepublikowane).

13. Kopiński J. (2017c), Ocena zmian efektywności wykorzystania azotu w produkcji rolniczej Polski. Rocz. Nauk. SERiA, 19(1), s. 88-94. https://doi.org/10.5604/01.3001.0009.8344

14. Kopiński J. (2014a), Określenie stopienia polaryzacji głównych kierunków produkcji zwierzęcej w Polsce. Roczn. Nauk. SERiA, t. 16, z. 2, s. 142-147.

15. Kopiński J. (2012), Realizacja celów środowiskowych i ekonomicznych w gospodarstwach o różnych kierunkach specjalizacji. Problemy Inżynierii Rolniczej, vol. 2(76), s. 37-45.

16. Kopiński J. (2013), Stopień polaryzacji intensywności i efektywności produkcji rolniczej w Polsce w ostatnich 10 latach. Roczn. Nauk. SERiA, 15(1), s. 97-103.

17. Kopiński J. (2017d), The comparison of changes in the implementation of production and environmental objectives of agriculture in selected groups of voivodships. Acta Sci. Pol. Oeconomia, vol. 16, issue 2, s. 87-95.

https://doi.org/10.22630/aspe.2017.16.2.21 
18. Kopiński J. (2014b), Trendy zmian głównych kierunków produkcji zwierzęcej w Polsce w okresie członkostwa Polski w UE, Wyd. Prace Naukowe UE we Wrocławiu, Wrocław, 361, s. 109-130.

19. Kopiński J., Krasowicz S. (2010), Regionalne zróżnicowanie warunków produkcji rolniczej w Polsce. Studia i Raporty IUNG-PIB, Puławy, 22, s. 9-29.

20. Kopiński J., Kuś J. (2011), Wpływ zmian organizacyjnych w rolnictwie na gospodarkę glebowq materiq organicznq̨. Prob. Inż. Rol., 2(72), s. 47-54.

21. Kopiński J., Matyka M. (2016), Ocena regionalnego zróżnicowania współzależności czynników przyrodniczych i organizacyjno -produkcyjnych w polskim rolnictwie. Zag. Ekon. Rol., 1(346), s. 57-79.

22. Kopiński J., Matyka M., Ochal P., Igras J. (2010), Tendencje zmian zużycia nawozów mineralnych w Polsce. Nawozy i Nawożenie - Fertilizers and fertilization, 41, s. 106-119.

23. Kopiński J., Nieróbca A. Ochal P. (2013), Ocena wpływu warunków pogodowych i zakwaszenia gleb w Polsce na kształtowanie produkcyjności roślinnej. Woda-Środowisko-Obszary Wiejskie, t. 13, z. 2(42), s. 53-63.

24. Kuś J. (2012), Produkcyjne i środowiskowe następstwa specjalizacji gospodarstw rolniczych. Studia i Raporty IUNG-PIB, Puławy, 29(3), s. 103-120.

25. Księżak J., Bojarszczuk J. (2016), Tendencje zmian produkcji i wykorzystania roślin pastewnych w Polsce. Studia i raporty IUNG-PIB, 47(1), s. 167-191.

26. Księżak J., Kopiński J. (2009), Czynniki decydujące o udziale roślin pastewnych w strukturze zasiewów. Wieś Jutra, 3(128), s. 24-26.

27. Matyka M. (2014), Plonowanie wybranych gatunków roślin uprawnych w Polsce, Niemczech i 27 krajach Unii Europejskiej w latach 1961-2012. Rocz. Nauk. SERiA, 16(3), s. 183-187.

28. Matyka M. (2013), Tendencje w zużyciu nawozów mineralnych w Polsce na tle Unii Europejskiej. Roczn. Nauk. SERiA, 15(3), s. 237-241.

29. Matyka M., Krasowicz S., Kopiński J., Kuś J. (2013), Regionalne zróżnicowanie zmian produkcji rolniczej w Polsce. Studia i Raporty IUNG-PIB, Puławy, 32(6), s. 143-165.

30. Niedzielski E. (2015), Funkcje obszarów wiejskich i ich rozwój. Zag. Ekon. Roln., 2, s. 84-93. https://doi.org/10.5604/00441600.1152187

31. Pastuszak M., Kowalkowski T., Kopiński J., Stalenga J., Panasiuk D. (2014), Impact of forecasted changes in Polish economy (2015 and 2020) on nutrient emission into the river basins. Sci. Total Environ., 493, s. 32-43. https://doi.org/10.1016/j.scitotenv.2014.05.124

32. Program Rozwoju Obszarów Wiejskich na lata 2007-2013 (2009), Mat. Inf. MRiRW, Warszawa.

33. Program Rozwoju Obszarów Wiejskich na lata 2014-2020 (2014), MRiRW, Warszawa, ss. 779. https://bip.minrol.gov.pl/content/download/46706/265161/version/2/file/Program\%20Rozwoju\%200bszar\%C3\%B3w\%20Wiejskich\%20na\%20 lata\%202014-2020a.pdf (data dostępu: 30.06.2017).

34. Produkcja upraw rolnych i ogrodniczych (2002-2016). GUS, Warszawa.

35. Rynek Ziemi Rolniczej (2016). Analizy rynkowe. Wyd. IERiGŻ-PIB, ANR, MRiRW, Warszawa, nr 19.

36. Rudnicki R., Wiśniewski Ł., Kluba M. (2015), Poziom i struktura przestrzenna rolnictwa Polskiego w świetle wyników Powszechnego Spisu Rolnego 2010. Rocz. Nauk. SERiA, 17(3), s. 335-343.

37. Runowski H. (2014), Ekonomika rolnictwa - przemiany w gospodarstwach rolnych, W: Rolnictwo, gospodarka żywnościowa, obszary wiejskie - 10 lat w Unii Europejskiej. SGGW, Warszawa, s. 31-48.

38. Stany M. (2013), Przestrzenne zróżnicowanie rozwoju obszarów wiejskich w Polsce. IRWiR-PAN, Warszawa.

39. Smagacz J. (2012), Produkcyjno-ekonomiczne i środowiskowe skutki rożnych systemów uprawy roli. Studia i Raporty IUNG-PIB, Puławy, 29(3), s. 121-134.

40. Strategia zrównoważonego rozwoju wsi, rolnictwa i rybactwa na lata 2012-2020 (2012), MRiRW, Warszawa.

41. Szajner P. (2017), Strategiczne aspekty rozwoju sektora cukrowniczego $w$ Polsce po reformie regulacji rynkowych $w 2017$., Mat. Konf. IERiGŻ-PIB, Licheń:http://ierigz.waw.pl/download/21076-Strategiczne_aspekty_rozwoju_sektora_cukrowniczego_w_Polsce_po_reformie_regulacji_rynkowych_w_2017_r..pdf (data dostępu: 30.10.2018).

42. Środki produkcji w rolnictwie (2000-2016), GUS, Warszawa.

43. Użytkowanie gruntów, powierzchnia zasiewów i pogłowie zwierząt gospodarskich (2000-2017). GUS, Warszawa.

44. Zasada Wzajemnej Zgodności (cross-compliance) (2012), MRiRW, Warszawa.

45. Zwierzęta gospodarskie (2013-2017). GUS, Warszawa.

46. Zegar J. (2013), Konkurencyjność celów ekologicznych i ekonomicznych w rolnictwie. IERiGŻ-PIB (PW 2011-2014), 93, s. 28-46.

47. Ziętara W. (2009), Tendencje zmian w produkcji mleka w Polsce. Rocz. Nauk Rol., Warszawa, ser. G, 96(1), s. 27-35. 